\title{
Creating Reciprocal Value Through Operational Transparency
}

\section{Citation}

Buell, Ryan W., Tami Kim, and Chia-Jung Tsay. "Creating Reciprocal Value Through Operational Transparency." Harvard Business School Working Paper, No. 14-115, May 2014. (Revised May 2015.)

\section{Permanent link}

http://nrs.harvard.edu/urn-3:HUL.InstRepos:13479246

\section{Terms of Use}

This article was downloaded from Harvard University's DASH repository, and is made available under the terms and conditions applicable to Open Access Policy Articles, as set forth at http:// nrs.harvard.edu/urn-3:HUL.InstRepos:dash.current.terms-of-use\#OAP

\section{Share Your Story}

The Harvard community has made this article openly available.

Please share how this access benefits you. Submit a story.

Accessibility 
H A R VARD D B U I N E S S S C H O O L

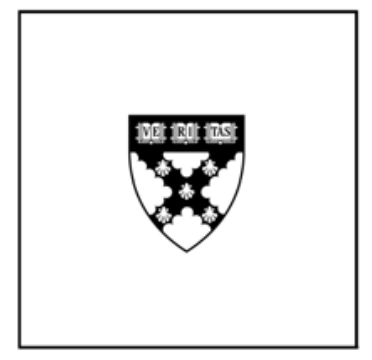

\section{Creating Reciprocal Value Through Operational Transparency}

Ryan W. Buell

Tami Kim

Chia-Jung Tsay

\section{Working Paper}

14-115

May 20, 2015 


\title{
Creating Reciprocal Value through Operational Transparency
}

\author{
Ryan W. Buell, Tami Kim \\ Harvard Business School, Harvard University, Boston, MA 02163 United States \\ rbuell@hbs.edu, tkim@hbs.edu \\ Chia-Jung Tsay \\ University College London, Gower Street, London, WC1E 6BT United Kingdom \\ c.tsay@ucl.ac.uk
}

\begin{abstract}
We investigate whether organizations can create value by introducing visual transparency between consumers and producers. Although operational transparency has been shown to improve consumer perceptions of service value, existing theory posits that increased contact between consumers and producers may diminish work performance. Two field and three laboratory experiments in food service settings suggest that transparency that 1) allows customers to observe operational processes and 2) allows employees to observe customers not only improves customer perceptions, but also increases service quality and efficiency. In our fully specified models, the introduction of reciprocal operational transparency contributed to a $22.2 \%$ increase in customerreported quality and reduced throughput times by $19.2 \%$. Laboratory studies revealed that customers who observed employees engaging in labor perceived greater effort, better appreciated that effort, and valued the service more. Employees who observed customers felt that their work was more appreciated and more impactful, and thus were more satisfied with their work and more willing to exert effort. We find that transparency, by visually revealing operating processes to consumers and beneficiaries to producers, generates a positive feedback loop through which value is created for both parties.
\end{abstract}

Key words: operational transparency; service quality; efficiency; perceived value; customers; employees

\section{Introduction}

At the local Krispy Kreme store, freshly glazed donuts move along on conveyer belts behind glass panes, beckoning customers to observe their production. From fast food chains such as Subway and Chipotle to high-end establishments presenting open kitchens, a wide range of restaurants celebrate the food creation process as much as the final dishes, through designs that introduce visual transparency into the customer experience. We have the intuition that seeing the process is meaningful, and we are often willing to pay a premium for such privilege. But does making the process transparent actually generate substantive benefits, and if so, for whom?

A growing body of literature has examined the effects of transparency on consumers and service providers. For example, recent research on operational transparency documents the perceptual 
benefits of showing customers the work conducted on their behalf during service transactions (Buell and Norton 2011, 2013, Mohan et al. 2014). Revealing the delivery process can improve perceptions of the service provider and of the experience (Mohr and Bitner 1995, Morales 2005). Relatedly, an understanding of the time and effort involved can enhance perceptions of outcome quality (Chinander and Schweitzer 2003, Kruger et al. 2004); moreover, visual information can influence and even dominate more relevant metrics of quality (Ambady and Rosenthal 1993, Benjamin and Shapiro 2009, Rule and Ambady 2008, Tsay 2013, 2014).

The present research focuses on reciprocal transparency, which provides customers and service providers with visual access to one another during service delivery. Building on prior research that highlights the perceptual benefits of revealing the operation to the customer, we demonstrate not only how reciprocal transparency achieves similar outcomes, but also how the benefits of transparency can accrue to the employee as well. In particular, we find that revealing the customer can increase employee effort, resulting in improved service quality and efficiency.

\section{Seeing and being seen: transparency, perceptions, and performance}

Existing research has supported the notion that organizations stand to gain by becoming more transparent to both internal and external stakeholders. For example, companies can achieve more positive outcomes by disclosing information on corporate social responsibility (Burke and Logsdon 1996, Dhaliwal et al. 2011, Du et al. 2007), privacy practices and policies (Pan and Zinkhan 2006, Tsai et al. 2010), and executive compensation (Lo 2003). Encouraging employee and consumer voice by allowing the co-creation of products (Franke et al. 2013, Norton et al. 2011) and seeking constructive feedback (Fast et al. 2014) could also help satisfy multiple stakeholders.

Transparency can be constructive at an interpersonal level as well, promoting teamwork in projects (Hackman and Coutu 2009, Hackman and Wageman 2004), increasing psychological closeness and smoothing social interactions (Pierce et al. 2013), facilitating negotiations between opposing parties (Malhotra and Bazerman 2007, Ross and Stillinger 1991), and reducing miscommunication and medical errors (Neergaard and Caruso 2014). Such dynamics can be quite relevant in considering interactions between consumers and employees (Gremler and Gwinner 2000, Parasuraman et al. 1985), as shared interests and common goals may not be as salient as the frustration and even hostility that may arise (Baker and Cameron 1996, Fornell and Westbrook 1979).

However, not all types of transparency are lauded. In fact, some findings may discourage organizations from adopting practices that subject their core processes to environmental influences (Thompson 1967). For service industries, transparency that allows interpersonal exchanges fits in this category. For example, broad or invasive managerial contact with employees can diminish efficiency and production performance (Bernstein 2012), and decrease job satisfaction while increasing 
turnover intention (Chalykoff and Kochan 1989). Similarly, it has long been theorized that when direct customer contact with a service system and its employees is high, the system's potential to operate at peak efficiency is diminished (Chase 1978, 1981). Accordingly, organizations may find it in their interests to create a work environment that protects employees from such uncertainties (Tansik and Chase 1983).

Furthermore, some research suggests that providing customers with a clearer understanding about organizational goals and processes could actually undermine firms' efforts to establish positive relationships with them. For example, the same disclosure about corporate social responsibility meant to generate positive outcomes could also prompt cynicism about motivations (Campbell and Kirmani 2000, Torelli et al. 2012, Yoon et al. 2006), and even undercut the exact goal that the organization is hoping to promote (Barasch et al. 2014). In addition, more knowledge about transactions provides additional opportunities for customers to recognize potential areas of improvement, increasing the likelihood of disappointment with companies (Wathieu 2004). Given that customers form expectations based on both past experiences and normative beliefs about how they should be treated (Bearden and Teel 1983, Boulding et al. 1993, Churchill Jr. and Surprenant 1982, Tse and Wilton 1988), the ability to observe employees could lead customers to develop unfair or unrealistic expectations during subsequent visits.

The literature to date, however, tends to be theoretical or focused on adverse contexts (e.g., when employees are at fault). There has been a relative dearth of empirical research on customeremployee contact and the ways in which organizations can use visual exchanges to create positive experiences for customers, employees, and organizations during ordinary service interactions.

The current research focuses on reciprocal transparency, an increasingly popular practice that has previously been little researched. Our work highlights this particular form of transparency, in which customers may observe service operations and processes, and employees may observe their customers. Building upon previous work that has demonstrated the possibility of reciprocal gains between customers and firms (Cialdini 2009, Regan 1971, Tidd and Lockard 1978), we propose that economic and psychological benefits can be achieved, without compromising efficiency, when customers and employees can visually access one another.

In this research, we focus specifically on the visual aspect of reciprocal transparency, rather than other aspects of interactions such as verbal or physical exchanges. We do so prompted by the strength of empirical support for the impact of visual information in a range of domains and for many consequential outcomes. Visual information is often privileged in perception and decision making (Ambady and Rosenthal 1993, Benjamin and Shapiro 2009, Rule and Ambady 2008, Tsay 2013, 2014) and thus in considering types of transparency, visual transparency has the potential to generate more substantive benefits than forms of transparency based on other 
types of sensory information. After all, there is a rich literature on the impact of even static visual information upon our preferences and tastes. In fact, such effects can develop remarkably early in life (Axelrod 1968, Haley and Case 1979, Robinson et al. 2007). With the consumption of similar or even identical goods, the subjective utility that we derive from those goods can differ dramatically based on a range of contextual cues, including price (Plassmann et al. 2008), brand (Brown and Eisenhardt 1997, McAlexander et al. 2002), and color (Spence et al. 2010, Zellner and Kautz 1990). Furthermore, access to visual information can facilitate consumers' awareness of the production process involved, leading to perceptions of higher product quality (Chinander and Schweitzer 2003, Kruger et al. 2004, Mohr and Bitner 1995, Morales 2005).

In addition, visual access can grant more than just information about the products or technical process to customers. Several literatures hint at the possibility of creating value for all parties simply by injecting a social element into the process and providing relevant visual information about standard operating processes. For example, allowing employees to see their customers could lead them to better identify with customers by reducing the perceived social distance (Gino et al. 2010, Small and Loewenstein 2005). People tend to be more sensitive to and more highly value a singular life over several lives (Friedrich et al. 1999); by extrapolation, seeing actual customers could similarly lead employees to focus on the individual, rather than considering customers as an aggregate, thus increasing the level of care and service. Such research suggests that seeing customers may serve as a source of empowerment for employees, through which they could develop a higher sense of self-efficacy (Conger and Kanungo 1988), prolonged motivation (Grant et al. 2007), and greater satisfaction (Hartline and Ferrell 1996, Snipes et al. 2005). Similarly, giving more insight into product development can promote greater loyalty in customers, who may identify more strongly with the company (Franke et al. 2010, Fuchs and Schreier 2011). In fact, making operations transparent can be a simple and effective way to build this relationship, by improving customer perceptions of the service provider (Buell and Norton 2011).

Although prior research suggests that positive outcomes can be achieved from transparent practices, it has focused on cases where operational transparency was exogenous to objective performance and where the potential benefits of transparency were far more limited. This was either because the service was automated (Buell and Norton 2011) or because the effort and observation were asynchronous (Buell and Norton 2013, Mohan et al. 2014). To our knowledge, the current experiments are the first to directly investigate the performance implications of reciprocal transparency, in which customers and employees are simultaneously revealed to one another during the service delivery process. This research, conducted in food service settings, contributes to the literature on service operations and consumer and organizational behavior in two main ways. 
First, we investigate how revealing employees actively engaged in service delivery affects customer perceptions of the service. Our results suggest that transparency in face-to-face service settings can improve customer perceptions of service value, and that this tendency generalizes to populations beyond the reach of Western media and culture. Interestingly, we find that revealing the employee who delivers the service is not enough. Rather, customers must observe employees actively engaged in the service delivery process for the benefits of transparency to accrue. Our results further suggest that the perceptual gains from transparency are independent of improvements in objective performance. Observing employees engaging in service delivery increases customer perceptions of effort, which promotes feelings of appreciation and enhances perceptions of service value.

Second, we investigate how revealing customers to actively engaged employees affects employee behavior during service delivery. We find that revealing the customer can improve actual employee service performance. In our field experiment, customer evaluations of food quality improved $22.2 \%$ and throughput time dropped to $80.8 \%$ of the baseline when customers and employees could observe one another. Further investigation suggests that revealing the customer either prior to or during the service delivery process leads employees to feel more appreciated and that their work is more impactful, which separately increases their willingness to exert effort and their satisfaction with their job.

Our work highlights the ways in which having reciprocal access to visual information — through operational transparency - can generate a positive feedback loop through which value is created for both employees and customers. These findings hold particular promise as significant value may be created and captured collectively, without requiring extensive investments or adjustments to existing operating systems, and without incurring the individual and organizational costs often associated with traditional monitoring strategies (Alder and Ambrose 2005, Chalykoff and Kochan 1989, Zweig and Webster 2002) and training programs.

\section{Presentation of experiments}

In five experiments, including two conducted in the field and three conducted in the lab, we investigate the effect of operational transparency on customer perceptions, employee behaviors and motivation, and outcomes in face-to-face service settings. In particular, we focus on the food service industry, which was a $\$ 2.55$ trillion business worldwide in 2012 (Johnson School and Gerson Lehrman Group 2012), and in 2015 is projected to reach a record high of $\$ 709.2$ billion in sales and employ 14 million people in the United States alone (National Restaurant Association 2015). As in many face-to-face service settings, in food service, customers and employees are typically proximate and work is performed on each customer's behalf. Although that work is not inherently unappealing, it is often conducted apart from the customers, making food service an ideal setting 
for exploring how operational transparency and visual access between customers and employees may affect and add value to service interactions in a broad array of domains.

In a first field experiment conducted in a university dining hall, we introduced reciprocal operational transparency, which enabled customers and chefs to see one another during the service process. We demonstrate that transparency improved customer perceptions of service value and food quality without affecting the consistency of service performance, and in fact reduced throughput time (Experiment 1). A subsequent field study, conducted at a different dining hall with a more heterogeneous population, provides converging evidence of the distinct positive effects of operational transparency on perceived and objective service performance (Experiment 2). We next turn to three laboratory experiments that illustrate the mechanisms underlying the effects for customers and employees. For customers, operational transparency can increase perceptions of effort, which lead them to feel more appreciative of the employees and perceive the service to be more valuable (Experiment 3A); we find that this effect holds across different cultural contexts (Experiment 3B). For employees, seeing the customer can increase feelings of being appreciated and their perceptions of the impact of their work, which can separately lead to increased job satisfaction and higher intended levels of effort (Experiment 4).

\subsection{Experiment 1: Effects of operational transparency on employees and customers}

In Experiment 1, we test the effects of operational transparency on the quality and efficiency of service delivered by chefs in a university dining hall, as well as on the service value perceptions of their customers. The study took place over a two-week period in a dining hall at a large university in the Northeastern United States. The dining hall serves up to 1,600 diners for three meals a day daily, and features four main sections: a grill station, two buffet stations, and a salad bar. Our study focused on the customers and chefs who interacted through the grill station, which offered made-to-order items (e.g. eggs, hamburgers, hot dogs, etc.) that were cooked in a kitchen area separated from customers by an opaque wall (Figure 1).

3.1.1. Participants All chefs working at the dining hall during the time of our study were provided informed consent materials in advance of the study and all volunteered to participate $\left(N=11,100 \%\right.$ male; $\left.M_{a g e}=47.83, \mathrm{SD}=11.58\right) .{ }^{12}$

Chefs' assignments were designated by dining hall managers through weekly schedules without input or influence from the research team. Although individual chefs were always assigned to

\footnotetext{
${ }^{1}$ We note that all of the chefs who delivered service during this experiment were male. Although this constraint does not allow us to test whether the effects of transparency on employees varies across genders, it does enable us to rule out homophily as an explanation for our results. In particular, as we document, all main effects based on customer survey responses held after controlling for the gender of the customer.

2 Throughout the paper, $M$ is used to denote means, and $S D$ is used to denote standard deviations.
} 


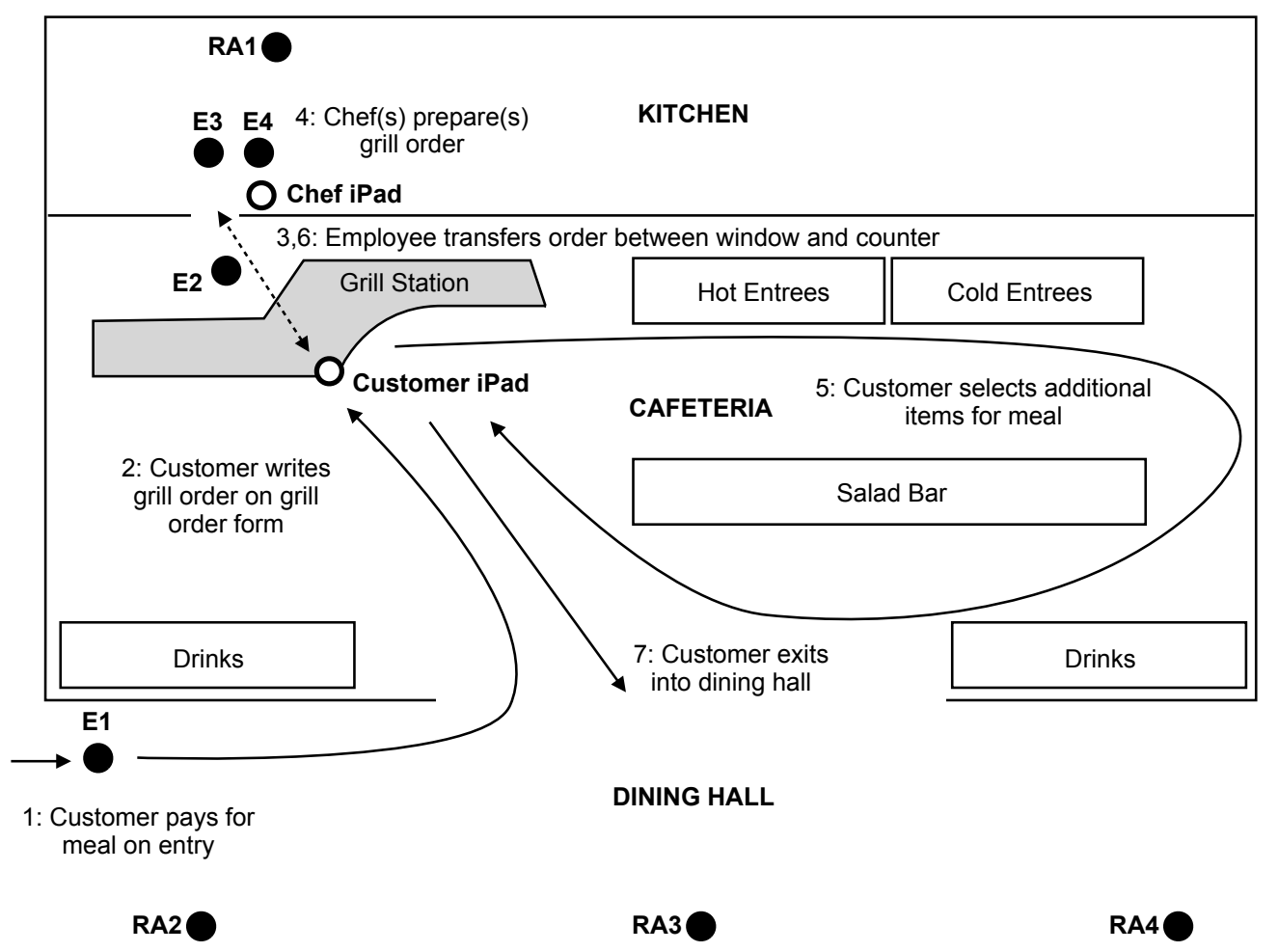

Figure 1 Layout of the cafeteria and typical customer flow during field experiment (Experiment 1)

Note: The label "RA" denotes research assistants; the label "E" represents employees.

the same shifts (breakfast and lunch shift, or dinner shift), there were numerous roles to which chefs could be assigned within each shift (e.g. prepping ingredients, preparing/refreshing the buffet stations, and staffing the grill station). Based on anticipated demand, one or two chefs were initially assigned to the grill station at the beginning of each shift. However, chefs were cross-trained and regularly rotated to help where needed throughout the kitchen. The absence of crossover employees between shifts, and the regular rotation of kitchen staff within shifts facilitated our empirical approach.

We surveyed 299 customers $\left(39.2 \%\right.$ female; $\left.M_{a g e}=21.1, \mathrm{SD}=4.31\right)$ who ordered food from the dining hall grill station during the period of analysis. ${ }^{3}$ Customers were predominantly students in a summer school program who had purchased a dining plan and accessed the dining hall for most of their meals. The selection of a sample of summer school students reduced the likelihood of ex-ante familiarity among customers and chefs. No inducements were offered to chefs or customers in exchange for their participation.

${ }^{3}$ Demographic questions were asked at the end of the survey; out of 299 total customer participants, 263 reported their gender and 275 reported their age. As our IRB approval did not allow for the collection of identifiable data, we were not able to determine the number of unique individuals who participated in the survey. 
3.1.2. Design and procedure To place an order from the grill station, customers filled out a grill order form and handed it to an employee who transferred the written order through a small window to the chefs in the kitchen. While waiting for their grill order item to be prepared, some customers would linger near the grill station, while others would move through the cafeteria, selecting drinks and additional hot and cold entrees. Meanwhile, chefs in the kitchen would prepare the item to order and pass the prepared item back through the window along with the original order form, thus ensuring returning customers received the correct items (Figure 1).

\begin{tabular}{|c|c|c|c|c|}
\hline Day & Meal & Transparency for chefs & Transparency for customers & Condition \\
\hline \multirow{2}{*}{ Monday (I) } & Lunch & Off & Off & Habituation \\
\hline & Dinner & Off & Off & Habituation \\
\hline \multirow{2}{*}{ Tuesday } & Lunch & Off & Off & Blind \\
\hline & Dinner & Off & Off & Blind \\
\hline \multirow{2}{*}{ Wednsday* } & Lunch & On & Off & Chef only \\
\hline & Dinner & Off & Off & Blind \\
\hline \multirow{2}{*}{ Thursday } & Lunch & On & On & Reciprocal transparency \\
\hline & Dinner & Off & On & Customer only \\
\hline \multirow{2}{*}{ Friday } & Lunch & On & On & Reciprocal transparency \\
\hline & Dinner & On & On & Reciprocal transparency \\
\hline \multirow{2}{*}{ Saturday (R) } & Lunch & Off & Off & Rehabituation \\
\hline & Dinner & Off & Off & Rehabituation \\
\hline \multirow{2}{*}{ Sunday (R) } & Lunch & Off & Off & Rehabituation \\
\hline & Dinner & Off & Off & Rehabituation \\
\hline \multirow{2}{*}{ Monday (I) } & Lunch & Off & Off & Habituation \\
\hline & Dinner & Off & Off & Habituation \\
\hline \multirow{2}{*}{ Tuesday } & Lunch & Off & Off & Blind \\
\hline & Dinner & On & Off & Chef only \\
\hline \multirow{2}{*}{ Wednesday } & Lunch & Off & On & Customer only \\
\hline & Dinner & On & On & Reciprocal transparency \\
\hline
\end{tabular}

Figure 2 Summary of staggered experimental treatment design (Experiment 1)

Note: $I$ indicates days equipment was installed. Shaded rows represent meals when behaviors were not measured. $R$ indicates period of rehabituation, during which the iPads were not installed. *During Wednesday dinner, the regular research assistant who timed chefs in the kitchen was not available. We dropped observations from this

dinner to eliminate the possibility of chefs behaving differently in response to a different research assistant.

However, we note that including these observations does not impact the relative performance of each condition for the dependent variables we analyze.

We manipulated the level of transparency by installing a pair of iPads with video conferencing software: one in the kitchen in view of the chefs, and another by the order submission station in view of the customers. The iPads were positioned to capture customers submitting orders and chefs preparing grill items. No sound was provided through either iPad, a design that ensured that only visual information was available to customers and employees without the possible effects of dyadic 
interactions or of information conveyed through other modalities (Tsay 2013, 2014). By installing these silent "virtual windows," we were able to investigate the directional effects of operational transparency in a 2 (customers: observe, do not observe the chefs) $\times 2$ (chefs: observe, do not observe the customers) experimental design. Conditions were enacted using a staggered treatment design. When the iPads were turned on for a population of employees or customers, they were not turned off again until the rehabituation period, which was scheduled in the middle of the experiment (Figure 2).

3.1.3. Data collection During each meal (11:30 am-2:00 pm for lunch; 4:30 pm-7:00 pm for dinner), four research assistants collected data from the chefs and customers. One research assistant, who was stationed in the kitchen, observed the behaviors of the chefs and timed the preparation of specific grill items. This research assistant recorded the throughput times of approximately ten randomly selected made-to-order grill items every 30 minutes, targeting 50 observations per shift. ${ }^{4}$ Three additional research assistants, who were stationed in the dining hall, surveyed the customers. ${ }^{5}$ Each of these research assistants circulated and approached customers who had ordered items from the grill station. Because the grill items were distinct from the buffet entrees, diners who had ordered from the grill station were easily identifiable. We set a collection target of 30 survey responses per mealtime, and assistants were instructed to balance data collection across each meal period, collectively surveying approximately ten diners every 50 minutes. ${ }^{6}$ After agreeing to participate, diners were given privacy as they completed a paper-based survey, which was collected by an assistant later in the meal. We note that these four research assistants were introduced before baseline measurements were taken. Hence, the effects attributed to our experimental manipulations are over and above any effect of having extra observers present in the kitchen or dining room.

3.1.4. Dependent measures We measured the effects of transparency on employees in three ways. First, we used customers' satisfaction with the food they ordered from the grill — "On a scale of 1 to 7, how satisfied are you with today's orders?" - as a measure of user-based quality (Edwards 1968, Garvin 1984, Gilmore 1974). Second, we used the throughput times of made-toorder grill items prepared by the on-duty chefs to measure the efficiency of employee performance

${ }^{4}$ We aimed to use the same research assistant in the kitchen throughout the study to ensure measurement consistency and to eliminate the possibility of the chefs responding differently to different research assistants. This research assistant was not available for one dinner shift, and although we used a substitute research assistant that shift to allow the study to proceed uninterrupted, we have excluded observations from that meal from our analysis. However, we note that including these observations does not impact the relative performance of each condition for the dependent variables we analyze.

${ }^{5}$ All studies described in this paper were approved in advance by the authors' Institution Review Board (IRB), and all assistants who helped administer these experiments were blind to the hypotheses and were certified to interact with human subjects. Across all studies, copies of informed consent forms were available for all participants, and with the exception of Experiment 2 as described below, no personally identifiable data were collected.

${ }^{6}$ Although precise response rate records were not kept, the vast majority of diners were amenable to participating. 
( $N=473$ orders). Finally, we assessed the consistency of employee throughput time, by calculating a normalized divergence metric for each item $i$ produced of type $t$, during a particular shift $s$. We multiplied the normalized divergence metric by -1 to create a measure that increases in consistency:

$$
\text { CONSISTENCY } Y_{i t s}=\frac{-\left|T P T_{i t s}-\overline{T P T}_{t s}\right|}{\sigma_{t s}}
$$

Data from these quality and efficiency measures should hold implications generalizable across a range of domains, including banking (Walfried et al. 2000), education (Jacob and Lefgren 2008), healthcare (Chassin and Galvin 1998, Jha 2006), service (Cronin Jr. and Taylor 1992), technology (Crowston et al. 2006), and the public sector (Rusbult 1979).

\begin{tabular}{|c|c|c|c|c|c|c|c|c|c|c|c|c|c|c|c|}
\hline & \multicolumn{3}{|c|}{ Blind } & \multicolumn{3}{|c|}{ Chefs only } & \multicolumn{3}{|c|}{ Customers only } & \multicolumn{3}{|c|}{ Reciprocal Transparency } & \multicolumn{3}{|c|}{ All } \\
\hline & $n$ & Mean & Std. Dev. & $n$ & Mean & Std. Dev. & $n$ & Mean & Std. Dev. & $n$ & Mean & Std. Dev. & $n$ & Mean & Std. Dev. \\
\hline $\begin{array}{l}\text { Food satisfaction } \\
\text { Perceived value } \\
\text { Dinner indicator } \\
\text { Employees scheduled } \\
\text { Grill order volume (per shift) } \\
\text { Age } \\
\text { Female pct. } \\
\text { Noticed iPads pct. }\end{array}$ & $\begin{array}{l}82 \\
83 \\
83 \\
83 \\
83 \\
76 \\
72 \\
71\end{array}$ & $\begin{array}{c}4.57 \\
4.44 \\
0.36 \\
5.64 \\
222.29 \\
21.70 \\
0.43 \\
0.24\end{array}$ & $\begin{array}{c}1.47 \\
1.11 \\
0.48 \\
0.48 \\
30.32 \\
5.40 \\
0.50 \\
0.43\end{array}$ & $\begin{array}{l}60 \\
60 \\
60 \\
60 \\
60 \\
54 \\
53 \\
54\end{array}$ & \begin{tabular}{|c|}
5.15 \\
4.70 \\
0.48 \\
5.52 \\
356.28 \\
21.20 \\
0.30 \\
0.44
\end{tabular} & $\begin{array}{c}1.23 \\
1.13 \\
0.50 \\
0.50 \\
36.79 \\
3.63 \\
0.46 \\
0.50\end{array}$ & $\begin{array}{l}45 \\
45 \\
45 \\
45 \\
45 \\
43 \\
39 \\
40\end{array}$ & $\begin{array}{c}4.87 \\
4.43 \\
0.67 \\
5.33 \\
301.00 \\
20.53 \\
0.36 \\
0.73\end{array}$ & $\begin{array}{c}1.58 \\
1.14 \\
0.48 \\
0.48 \\
57.21 \\
3.06 \\
0.49 \\
0.45\end{array}$ & $\begin{array}{c}108 \\
111 \\
111 \\
111 \\
111 \\
102 \\
99 \\
95\end{array}$ & $\begin{array}{c}5.49 \\
5.19 \\
0.49 \\
5.29 \\
246.74 \\
20.90 \\
0.42 \\
0.69\end{array}$ & $\begin{array}{c}1.41 \\
1.01 \\
0.50 \\
0.46 \\
35.32 \\
4.18 \\
0.50 \\
0.46\end{array}$ & $\begin{array}{l}295 \\
299 \\
299 \\
299 \\
299 \\
275 \\
263 \\
260\end{array}$ & $\begin{array}{c}5.07 \\
4.77 \\
0.48 \\
5.44 \\
270.10 \\
21.12 \\
0.39 \\
0.52\end{array}$ & $\begin{array}{c}1.46 \\
1.13 \\
0.50 \\
0.50 \\
62.80 \\
4.31 \\
0.49 \\
0.50\end{array}$ \\
\hline $\begin{array}{l}\text { Throughput time (sec.) } \\
\text { Consistency } \\
\text { Time frame } \\
\text { Employees scheduled } \\
\text { Dinner indicator } \\
\text { Grill order volume (per shift) } \\
\text { Fish sandwich pct. } \\
\text { Eggs pct. } \\
\text { Egg whites pct. } \\
\text { Scrambled eggs pct. }\end{array}$ & $\begin{array}{l}125 \\
125 \\
125 \\
125 \\
125 \\
125 \\
125 \\
125 \\
125 \\
125\end{array}$ & $\begin{array}{l}58.50 \\
(0.78) \\
2.86 \\
5.62 \\
0.38 \\
226.98 \\
0.07 \\
0.26 \\
0.38 \\
0.30\end{array}$ & $\begin{array}{c}43.77 \\
0.56 \\
1.47 \\
0.49 \\
0.49 \\
32.87 \\
0.26 \\
0.44 \\
0.49 \\
0.46\end{array}$ & $\begin{array}{l}98 \\
98 \\
98 \\
98 \\
98 \\
98 \\
98 \\
98 \\
98 \\
98\end{array}$ & \begin{tabular}{|c|}
72.66 \\
$(0.75)$ \\
2.90 \\
5.46 \\
0.54 \\
360.48 \\
0.12 \\
0.29 \\
0.22 \\
0.37
\end{tabular} & $\begin{array}{c}39.18 \\
0.60 \\
1.45 \\
0.50 \\
0.50 \\
36.57 \\
0.33 \\
0.45 \\
0.42 \\
0.48\end{array}$ & $\begin{array}{l}65 \\
65 \\
65 \\
65 \\
65 \\
65 \\
65 \\
65 \\
65 \\
65\end{array}$ & $\begin{array}{c}65.02 \\
(0.80) \\
2.74 \\
5.65 \\
0.35 \\
263.46 \\
0.00 \\
0.38 \\
0.26 \\
0.35\end{array}$ & $\begin{array}{c}45.10 \\
0.52 \\
1.50 \\
0.48 \\
0.48 \\
57.83 \\
0.00 \\
0.49 \\
0.44 \\
0.48\end{array}$ & $\begin{array}{l}185 \\
185 \\
185 \\
185 \\
185 \\
185 \\
185 \\
185 \\
185 \\
185\end{array}$ & $\begin{array}{c}55.35 \\
(0.77) \\
2.84 \\
5.27 \\
0.44 \\
252.16 \\
0.10 \\
0.32 \\
0.21 \\
0.37\end{array}$ & $\begin{array}{c}38.28 \\
0.57 \\
1.46 \\
0.45 \\
0.50 \\
36.20 \\
0.30 \\
0.47 \\
0.41 \\
0.48\end{array}$ & $\begin{array}{l}473 \\
473 \\
473 \\
473 \\
473 \\
473 \\
473 \\
473 \\
473 \\
473\end{array}$ & $\begin{array}{c}61.10 \\
(0.77) \\
2.84 \\
5.45 \\
0.43 \\
269.50 \\
0.08 \\
0.30 \\
0.26 \\
0.35\end{array}$ & $\begin{array}{c}41.36 \\
0.57 \\
1.47 \\
0.50 \\
0.50 \\
61.99 \\
0.28 \\
0.46 \\
0.44 \\
0.48\end{array}$ \\
\hline
\end{tabular}

Table 1 Summary statistics (Experiment 1)

We also investigated whether customer perceptions of service value are affected by operational transparency in face-to-face domains. These perceptions are important predictors of longer-term behaviors, such as willingness to pay, satisfaction, and loyalty (McDougall and Levesque 2000). We measured them using the following adapted four-item scale: "The grill station provides a service I want to use," "The grill station offers a high quality service," "Other people would approve of the grill station," and "I am willing to pay to use the grill station." Participants provided responses on a 7-point scale, and we averaged these four items to create a composite measure of perceived service value. We note that this composite measure had a high Chronbach's Alpha, indicating high internal consistency $(\alpha=0.71)$ (Sweeney and Soutar 2001). 
3.1.5. Control variables We also account for a variety of additional factors in our analyses that varied over the period of our study. In modeling customer satisfaction and perceived value survey responses, we control for the meal (lunch or dinner), the number of employees scheduled to work in the kitchen during the shift, the number of grill orders placed during the shift (grill order volume), and the age and gender of survey respondents. In addition to the relevant variables described above, when modeling throughput time and employee consistency, we control for the item being produced, ${ }^{7}$ as well as indicator variables representing the shift's phase of completion (broken down into 30 minute increments) (Deo et al. 2014). Due to the non-linear effect of busyness on the rate of employee production (Oliva and Sterman 2001, Kc and Terwiesch 2009), we also include a quadratic grill order volume term. ${ }^{8}$

3.1.6. Analysis and results We model food satisfaction, throughput time, consistency, and perceived value, $Y$, as a linear function of each treatment condition: (1) CHEFONLY, when chefs could observe the customers, but customers could not observe the chefs; (2) CUSTONLY, when customers could observe the chefs, but chefs could not observe the customers; and (3) RECIPROCAL, when chefs and customers could observe each other; as well as a vector of controls, $X$, as described above. This specification facilitates the direct interpretation of the coefficient corresponding with each treatment condition as the performance difference relative to the baseline control condition, in which neither the chefs nor the customers could observe each other. Food satisfaction and perceived value are modeled with robust standard errors, clustered by meal and day; chef throughput time and consistency are modeled with robust standard errors, clustered by item, meal, and day.

$$
Y=f\left(\alpha_{0}+\alpha_{1} C H E F O N L Y+\alpha_{2} C U S T O N L Y+\alpha_{3} R E C I P R O C A L+\alpha_{4} X+\epsilon\right)
$$

Effects of transparency on employees In Table (2), Column (1), we compare the mean food satisfaction - our operationalization of food quality — produced under each experimental condition. Reciprocal transparency, in which both chefs and customers could observe each other, led to the largest gains in food satisfaction, $\left(\alpha_{3}=0.918, p<0.01\right)$. Although allowing the customers to see the chefs did not increase customer food satisfaction on its own, $\left(\alpha_{2}=0.293, p=N S\right)$, chefs who saw

\footnotetext{
${ }^{7}$ We limited our observations to fish sandwiches, fried eggs, egg whites, and scrambled eggs. The grill station also served turkey burgers, grilled chicken sandwiches, crispy fish sandwiches, Halal hot dogs, Halal hamburgers, garden burgers, tofu dogs, bean burritos, and chicken patties. We refrained from tracking these items because they were either ordered in extremely limited quantities, or were served directly from warming trays and not actively cooked to order.

${ }^{8}$ We note that grill order volume did not have a non-linear effect on customer evaluations of the service, and that the incorporation of a quadratic grill order volume term reduced the fit of models of customer satisfaction and value perceptions, without substantively affecting the coefficients of interest.
} 


\begin{tabular}{|c|c|c|c|c|c|}
\hline & $(1)$ & (2) & (3) & (4) & (5) \\
\hline & $\begin{array}{c}\text { Food } \\
\text { satisfaction }\end{array}$ & $\begin{array}{c}\text { Food } \\
\text { satisfaction }\end{array}$ & $\begin{array}{c}\text { Food } \\
\text { satisfaction }\end{array}$ & $\begin{array}{c}\text { Food } \\
\text { satisfaction }\end{array}$ & $\begin{array}{c}\text { Food } \\
\text { satisfaction }\end{array}$ \\
\hline 1. Chefs only & $\begin{array}{l}0.577^{* *} \\
(0.225)\end{array}$ & $\begin{array}{l}0.598^{* *} \\
(0.192)\end{array}$ & $\begin{array}{l}0.602^{* *} \\
(0.190)\end{array}$ & $\begin{array}{c}0.659 \\
(0.438)\end{array}$ & $\begin{array}{l}0.651^{*} \\
(0.314)\end{array}$ \\
\hline 2. Customer only & $\begin{array}{c}0.293 \\
(0.208)\end{array}$ & $\begin{array}{c}0.347 \\
(0.217)\end{array}$ & $\begin{array}{c}0.358 \\
(0.226)\end{array}$ & $\begin{array}{c}0.391 \\
(0.355)\end{array}$ & $\begin{array}{c}0.223 \\
(0.270)\end{array}$ \\
\hline 3. Reciprocal transparency & $\begin{array}{c}0.918^{* * *} \\
(0.238)\end{array}$ & $\begin{array}{c}0.940^{* * *} \\
(0.216)\end{array}$ & $\begin{array}{c}0.996^{* * *} \\
(0.211)\end{array}$ & $\begin{array}{c}0.998^{* * *} \\
(0.215)\end{array}$ & $\begin{array}{l}1.003^{* * *} \\
(0.126)\end{array}$ \\
\hline 4. Dinner indicator & & $\begin{array}{c}-0.177 \\
(0.124)\end{array}$ & $\begin{array}{l}0.0158 \\
(0.118)\end{array}$ & $\begin{array}{r}-0.0120 \\
(0.193)\end{array}$ & $\begin{array}{c}0.149 \\
(0.139)\end{array}$ \\
\hline 5. Employees scheduled & & & $\begin{array}{c}0.231 \\
(0.145)\end{array}$ & $\begin{array}{c}0.199 \\
(0.266)\end{array}$ & $\begin{array}{l}0.440^{* *} \\
(0.166)\end{array}$ \\
\hline 6. Grill order volume (per shift) & & & & $\begin{array}{r}-0.000430 \\
(0.00235)\end{array}$ & $\begin{array}{c}0.00000858 \\
(0.00172)\end{array}$ \\
\hline 7. Age & & & & & $\begin{array}{r}-0.00975 \\
(0.0262)\end{array}$ \\
\hline 8. Female indicator & & & & & $\begin{array}{l}0.367^{*} \\
(0.168)\end{array}$ \\
\hline Constant & $\begin{array}{c}4.573^{* * *} \\
(0.197)\end{array}$ & $\begin{array}{c}4.638^{* * *} \\
(0.227)\end{array}$ & $\begin{array}{c}3.266^{* * *} \\
(0.795)\end{array}$ & $\begin{array}{l}3.554^{*} \\
(1.919)\end{array}$ & $\begin{array}{c}2.113 \\
(1.453)\end{array}$ \\
\hline Observations & 295 & 295 & 295 & 295 & 254 \\
\hline Adjusted R-squared & 0.056 & 0.057 & 0.055 & 0.052 & 0.066 \\
\hline Pred. difference relative to baseline (Chef only) & $12.61 \%$ & $13.13 \%$ & $13.29 \%$ & $14.61 \%$ & $14.41 \%$ \\
\hline Pred. difference relative to baseline (Both only) & $20.06 \%$ & $20.64 \%$ & $21.98 \%$ & $22.13 \%$ & $22.19 \%$ \\
\hline
\end{tabular}

Table 2 Models of food satisfaction survey responses (Experiment 1)

***, ** and * denote significance at the $1 \%, 5 \%$ and $10 \%$ levels, respectively (two-tailed tests). Parentheses contain robust standard errors, clustered by meal and day. Predicted differences represent percentage increase over baseline condition. Although we use OLS in our primary analysis to facilitate coefficient interpretation, we note that all reported results are substantively similar when food satisfaction is estimated with an ordinal logistic model.

the customers produced food that again led to significantly higher food satisfaction, even when customers could not see the chefs $\left(\alpha_{1}=0.577, p<0.05\right)$. Columns $(2)$ and $(3)$ show that these patterns persist after controlling for meal and the number of employees scheduled. Interestingly, controlling for grill order volume in Column (4) diminishes the effect of food satisfaction to insignificance when only the chef can observe the customer, $\left(\alpha_{1}=0.6591, p=N S\right)$, while strengthening the effect of transparency when both chefs and customers could observe each other $\left(\alpha_{3}=0.998, p<0.01\right)$. Column (5) shows that these results are robust to the inclusion of controls for age and gender. Relative to the baseline condition, in the fully-specified model, food satisfaction was $14.4 \%$ higher when chefs could observe customers and $22.2 \%$ higher when chefs and employees could observe one another. 


\begin{tabular}{|c|c|c|c|c|c|c|c|c|}
\hline & (1) & $(2)$ & (3) & $(4)$ & (5) & $(6)$ & (7) & (8) \\
\hline & $\begin{array}{c}\text { Throughput } \\
\text { time }\end{array}$ & $\begin{array}{l}\text { Throughput } \\
\text { time }\end{array}$ & $\begin{array}{c}\text { Throughput } \\
\text { time }\end{array}$ & $\begin{array}{c}\text { Throughput } \\
\text { time }\end{array}$ & Consistency & Consistency & Consistency & Consistency \\
\hline 1. Chefs only & $\begin{array}{c}10.73 \\
(6.650)\end{array}$ & $\begin{array}{c}9.988 \\
(6.064)\end{array}$ & $\begin{array}{c}9.998 \\
(6.180)\end{array}$ & $\begin{array}{c}1.061 \\
(7.657)\end{array}$ & $\begin{array}{l}0.0334^{*} \\
(0.0191)\end{array}$ & $\begin{array}{c}0.0323 \\
(0.0198)\end{array}$ & $\begin{array}{c}0.0294 \\
(0.0203)\end{array}$ & $\begin{array}{c}0.0235 \\
(0.0353)\end{array}$ \\
\hline 2. Customers only & $\begin{array}{l}-3.029 \\
(6.214)\end{array}$ & $\begin{array}{l}-2.990 \\
(5.737)\end{array}$ & $\begin{array}{l}-2.896 \\
(5.808)\end{array}$ & $\begin{array}{l}-4.397 \\
(5.060)\end{array}$ & $\begin{array}{l}-0.0129 \\
(0.0273)\end{array}$ & $\begin{array}{c}-0.0128 \\
(0.0276)\end{array}$ & $\begin{array}{l}-0.0186 \\
(0.0293)\end{array}$ & $\begin{array}{l}-0.0207 \\
(0.0317)\end{array}$ \\
\hline 3. Reciprocal transparency & $\begin{array}{l}-7.586 \\
(6.563)\end{array}$ & $\begin{array}{c}-14.89^{* *} \\
(6.900)\end{array}$ & $\begin{array}{c}-14.88^{* *} \\
(6.990)\end{array}$ & $\begin{array}{l}-12.75^{*} \\
(7.150)\end{array}$ & $\begin{array}{c}0.0154 \\
(0.0228)\end{array}$ & $\begin{array}{l}0.00373 \\
(0.0253)\end{array}$ & $\begin{array}{l}0.00334 \\
(0.0248)\end{array}$ & $\begin{array}{l}0.00214 \\
(0.0275)\end{array}$ \\
\hline 4. Eggs indicator & $\begin{array}{c}86.16^{\star * *} \\
(7.932)\end{array}$ & $\begin{array}{c}87.09^{* * *} \\
(6.763)\end{array}$ & $\begin{array}{c}86.21^{\star \star *} \\
(6.697)\end{array}$ & $\begin{array}{c}86.39^{* * *} \\
(6.786)\end{array}$ & $\begin{array}{c}-0.0595^{\star *} \\
(0.0277)\end{array}$ & $\begin{array}{l}-0.0580^{*} \\
(0.0304)\end{array}$ & $\begin{array}{l}-0.0423 \\
(0.0314)\end{array}$ & $\begin{array}{c}-0.0422 \\
(0.0314)\end{array}$ \\
\hline 5. Egg whites indicator & $\begin{array}{c}19.18^{* * *} \\
(6.158)\end{array}$ & $\begin{array}{c}20.88^{* * *} \\
(5.599)\end{array}$ & $\begin{array}{c}20.33^{* \star *} \\
(5.608)\end{array}$ & $\begin{array}{c}20.21^{* \star *} \\
(5.668)\end{array}$ & $\begin{array}{c}-0.0138 \\
(0.0318)\end{array}$ & $\begin{array}{c}-0.0111 \\
(0.0337)\end{array}$ & $\begin{array}{r}-0.00173 \\
(0.0329)\end{array}$ & $\begin{array}{r}-0.00193 \\
(0.0329)\end{array}$ \\
\hline 6. Scrambled indicator & $\begin{array}{c}17.43^{* \star *} \\
(6.152)\end{array}$ & $\begin{array}{c}19.91^{* \star *} \\
(5.512)\end{array}$ & $\begin{array}{c}19.53^{* \star *} \\
(5.541)\end{array}$ & $\begin{array}{l}19.69^{* \star *} \\
(5.668)\end{array}$ & $\begin{array}{c}-0.0473 \\
(0.0303)\end{array}$ & $\begin{array}{c}-0.0434 \\
(0.0315)\end{array}$ & $\begin{array}{l}-0.0383 \\
(0.0303)\end{array}$ & $\begin{array}{l}-0.0378 \\
(0.0306)\end{array}$ \\
\hline 7. Dinner indicator & $\begin{array}{c}15.33^{* \star *} \\
(4.936)\end{array}$ & $\begin{array}{l}-3.979 \\
(4.915)\end{array}$ & $\begin{array}{l}-4.994 \\
(4.802)\end{array}$ & $\begin{array}{l}-6.395 \\
(5.475)\end{array}$ & $\begin{array}{l}-0.0305^{*} \\
(0.0177)\end{array}$ & $\begin{array}{l}-0.0613 \\
(0.0383)\end{array}$ & $\begin{array}{l}-0.0391 \\
(0.0389)\end{array}$ & $\begin{array}{l}-0.0342 \\
(0.0420)\end{array}$ \\
\hline 8. Employees scheduled & & $\begin{array}{c}-24.15^{\star * *} \\
(5.219)\end{array}$ & $\begin{array}{c}-24.39^{* * *} \\
(5.286)\end{array}$ & $\begin{array}{c}-20.19^{* * *} \\
(7.282)\end{array}$ & & $\begin{array}{l}-0.0386 \\
(0.0396)\end{array}$ & $\begin{array}{l}-0.0340 \\
(0.0421)\end{array}$ & $\begin{array}{l}-0.0306 \\
(0.0466)\end{array}$ \\
\hline 9. Time frame 2 indicator & & & $\begin{array}{l}-0.0761 \\
(2.903)\end{array}$ & $\begin{array}{l}-0.189 \\
(2.834)\end{array}$ & & & $\begin{array}{l}0.00229 \\
(0.0800)\end{array}$ & $\begin{array}{l}0.00209 \\
(0.0805)\end{array}$ \\
\hline 10. Time frame 3 indicator & & & $\begin{array}{c}1.376 \\
(2.785)\end{array}$ & $\begin{array}{c}1.209 \\
(2.800)\end{array}$ & & & $\begin{array}{l}-0.0228 \\
(0.0767)\end{array}$ & $\begin{array}{l}-0.0228 \\
(0.0768)\end{array}$ \\
\hline 11. Time frame 4 indicator & & & $\begin{array}{c}2.324 \\
(3.348)\end{array}$ & $\begin{array}{c}2.534 \\
(3.328)\end{array}$ & & & $\begin{array}{c}-0.0950 \\
(0.0772)\end{array}$ & $\begin{array}{l}-0.0950 \\
(0.0774)\end{array}$ \\
\hline 12. Time frame 5 indicator & & & $\begin{array}{l}7.424^{* *} \\
(3.250)\end{array}$ & $\begin{array}{l}7.470^{* *} \\
(3.241)\end{array}$ & & & $\begin{array}{l}-0.124^{*} \\
(0.0731)\end{array}$ & $\begin{array}{l}-0.124^{*} \\
(0.0732)\end{array}$ \\
\hline 13. Grill order volume & & & & $\begin{array}{l}-0.494 \\
(0.403)\end{array}$ & & & & $\begin{array}{c}0.0003 \\
(0.0017)\end{array}$ \\
\hline 14. Grill order volume ${ }^{2}$ & & & & $\begin{array}{c}0.001 \\
(0.001)\end{array}$ & & & & $\begin{array}{l}-0.0000 \\
(0.0000)\end{array}$ \\
\hline Constant & $\begin{array}{c}18.31^{* * *} \\
(6.466)\end{array}$ & $\begin{array}{c}159.8^{* * *} \\
(31.97)\end{array}$ & $\begin{array}{c}160.0^{* \star *} \\
(33.06)\end{array}$ & $\begin{array}{c}198.3^{* * *} \\
(66.92)\end{array}$ & $\begin{array}{c}-0.732^{* * *} \\
(0.0282)\end{array}$ & $\begin{array}{c}-0.505^{\star *} \\
(0.241)\end{array}$ & $\begin{array}{l}-0.505^{*} \\
(0.270)\end{array}$ & $\begin{array}{l}-0.566 \\
(0.357)\end{array}$ \\
\hline Observations & 473 & 473 & 473 & 473 & 473 & 473 & 473 & 473 \\
\hline Adjusted R-squared & 0.667 & 0.690 & 0.692 & 0.695 & -0.012 & -0.014 & -0.015 & -0.019 \\
\hline Pred. Effect (Baseline) & 62.26 & 65.26 & 65.24 & 66.47 & & & & \\
\hline Pred. Effect (Chefs only) & 72.99 & 75.25 & 75.24 & 67.53 & & & & \\
\hline Pred. Effect (Customers only) & 59.23 & 62.27 & 62.35 & 62.07 & & & & \\
\hline Pred. Effect (Both only) & 54.67 & 50.37 & 50.37 & 53.72 & & & & \\
\hline
\end{tabular}

Table 3 Models of throughput time and consistency (Experiment 1)

$* * *, * *$ and $*$ denote significance at the $1 \%, 5 \%$, and $10 \%$ levels, respectively (two-tailed tests). Parentheses contain robust standard errors, clustered by item, meal, and day. Predicted effects are shown in seconds and may be interpreted as the average throughput time in a particular condition, after controlling for the factors in each model.

Do these quality gains come at the expense of efficiency? In Table (3), we test the effects of transparency on the throughput time and consistency of food production. Column (1) shows that relative to the baseline condition, average throughput time for orders was unaffected by the different transparency treatments, with items being prepared at an average of $117.2 \%$ of standard when chefs could see the customers $\left(\alpha_{1}=10.73, p=N S\right), 95.1 \%$ of standard when customers could see 
the chefs $\left(\alpha_{2}=-3.03, p=N S\right)$, and $87.8 \%$ of standard when customers and chefs could see each other $\left(\alpha_{3}=-7.59, p=N S\right)$. These differences became more significant with the introduction of controls. In Columns (2-4), we find that these results are amplified by the inclusion of controls for the number of employees scheduled, the time frame within the shift, and grill order volume. The fully-specified model reveals that employees worked faster during high-demand periods when more employees were scheduled $\left(\alpha_{8}=-20.19, p<0.01\right)$, and slower during the final 30 minutes of the shift $\left(\alpha_{12}=7.47, p<0.05\right)$. Controlling for these factors, allowing chefs and customers to observe each other reduced throughput times to $80.8 \%$ of standard $\left(\alpha_{3}=-12.75, p<0.10\right)$. In Columns $(5$ 8 ), we observe that the consistency of throughput times was largely unaffected by the introduction of transparency between chefs and customers, with a modest improvement in consistency stemming from allowing chefs to see their customers in Column $(5),\left(\alpha_{1}=0.032, p<0.10\right)$.

These results suggest that the quality improvements brought about by operational transparency need not jeopardize the responsiveness or consistency of the operating system. In fact, under reciprocal transparency, when quality ratings are at their highest, we find that responsiveness actually improved. In these conditions, employees were observed being more conscientious about processing orders when they arrived and were less likely to overcook items than in the baseline condition.

Effects of transparency on customers Consistent with the food satisfaction results, Table (4), Column (1) shows that when customers and chefs could observe one another, customers perceived the service to be more valuable $\left(\alpha_{3}=0.754, p<0.01\right)$ than when they could not. Relative to the baseline, perceived value was unchanged when only one side could see the other, both when chefs could observe customers who could not see them $\left(\alpha_{1}=0.263, p=N S\right)$ and when customers could observe chefs who could not see them $\left(\alpha_{2}=-0.012, p=N S\right)$. Columns $(2-5)$ demonstrate that the effects of reciprocal transparency intensify as controls are added for the type of meal, the number of scheduled employees, the grill order volume, and the age and gender of survey respondents. In the fully specified model, relative to the baseline control, customers perceive the service to be $18.51 \%$ more valuable under reciprocal transparency $\left(\alpha_{3}=0.818, p<0.01\right)$. Interestingly, Columns $(6-7)$ demonstrate that these differences in perceived value may not be fully explained by the differences in food quality. In the fully specified model, $41.81 \%$ of the improved value perception persists $\left(\alpha_{3}=\right.$ $0.342, p<0.01)$ after controlling for food satisfaction, which itself is a highly significant predictor of perceived value $\left(\alpha_{4}=0.496, p<0.01\right)$. These findings are consistent with the notions that 1$)$ customer perceptions of value in service settings may improve when operational transparency is reciprocal and 2) both objective and perceptual factors distinctly contribute to the gains engendered by transparency, which we next corroborate in an additional field experiment. 


\begin{tabular}{|c|c|c|c|c|c|c|c|}
\hline & $(1)$ & $(2)$ & (3) & $(4)$ & (5) & $(6)$ & $(7)$ \\
\hline & $\begin{array}{c}\text { Perceived } \\
\text { value }\end{array}$ & $\begin{array}{l}\text { Perceived } \\
\text { value }\end{array}$ & $\begin{array}{c}\text { Perceived } \\
\text { value }\end{array}$ & $\begin{array}{l}\text { Perceived } \\
\text { value }\end{array}$ & $\begin{array}{l}\text { Perceived } \\
\text { value }\end{array}$ & $\begin{array}{c}\text { Perceived } \\
\text { value }\end{array}$ & $\begin{array}{l}\text { Perceived } \\
\text { value }\end{array}$ \\
\hline 1. Chefs only & $\begin{array}{c}0.263 \\
(0.212)\end{array}$ & $\begin{array}{c}0.269 \\
(0.198)\end{array}$ & $\begin{array}{c}0.271 \\
(0.195)\end{array}$ & $\begin{array}{c}0.294 \\
(0.429)\end{array}$ & $\begin{array}{c}0.283 \\
(0.447)\end{array}$ & $\begin{array}{c}-0.0216 \\
(0.227)\end{array}$ & $\begin{array}{c}-0.0315 \\
(0.285)\end{array}$ \\
\hline 2. Customer only & $\begin{array}{r}-0.0120 \\
(0.239)\end{array}$ & $\begin{array}{c}0.00338 \\
(0.253)\end{array}$ & $\begin{array}{c}0.00697 \\
(0.258)\end{array}$ & $\begin{array}{l}0.0204 \\
(0.383)\end{array}$ & $\begin{array}{r}-0.0286 \\
(0.401)\end{array}$ & $\begin{array}{l}-0.159 \\
(0.211)\end{array}$ & $\begin{array}{c}-0.128 \\
(0.261)\end{array}$ \\
\hline 3. Reciprocal transparency & $\begin{array}{c}0.754^{* * *} \\
(0.163)\end{array}$ & $\begin{array}{c}0.760^{* * *} \\
(0.158)\end{array}$ & $\begin{array}{c}0.777^{* * *} \\
(0.162)\end{array}$ & $\begin{array}{c}0.778^{* * *} \\
(0.167)\end{array}$ & $\begin{array}{c}0.818^{* * *} \\
(0.139)\end{array}$ & $\begin{array}{l}0.304^{* * *} \\
(0.0570)\end{array}$ & $\begin{array}{l}0.342^{* * *} \\
(0.0704)\end{array}$ \\
\hline 4. Food satisfaction & & & & & & $\begin{array}{l}0.497^{* * *} \\
(0.0299)\end{array}$ & $\begin{array}{l}0.496^{* * *} \\
(0.0402)\end{array}$ \\
\hline 5. Dinner indicator & & $\begin{array}{l}-0.0503 \\
(0.120)\end{array}$ & $\begin{array}{l}0.00748 \\
(0.0801)\end{array}$ & $\begin{array}{c}-0.00410 \\
(0.194)\end{array}$ & $\begin{array}{c}0.198 \\
(0.211)\end{array}$ & $\begin{array}{l}0.0146 \\
(0.116)\end{array}$ & $\begin{array}{c}0.133 \\
(0.161)\end{array}$ \\
\hline 6. Employees scheduled & & & $\begin{array}{l}0.0696 \\
(0.120)\end{array}$ & $\begin{array}{l}0.0562 \\
(0.217)\end{array}$ & $\begin{array}{c}0.253 \\
(0.182)\end{array}$ & $\begin{array}{l}-0.0366 \\
(0.0974)\end{array}$ & $\begin{array}{l}0.0387 \\
(0.124)\end{array}$ \\
\hline 7. Grill order volume (per shift) & & & & $\begin{array}{r}-0.000178 \\
(0.00244)\end{array}$ & $\begin{array}{l}0.000262 \\
(0.00254)\end{array}$ & $\begin{array}{l}0.000106 \\
(0.00139)\end{array}$ & $\begin{array}{l}0.000345 \\
(0.00170)\end{array}$ \\
\hline 8. Age & & & & & $\begin{array}{l}0.00504 \\
(0.0186)\end{array}$ & & $\begin{array}{l}0.00665 \\
(0.0129)\end{array}$ \\
\hline 9. Female indicator & & & & & $\begin{array}{l}0.224^{*} \\
(0.115)\end{array}$ & & $\begin{array}{c}0.0267 \\
(0.0804)\end{array}$ \\
\hline Constant & $\begin{array}{c}4.440^{* * *} \\
(0.147)\end{array}$ & $\begin{array}{c}4.458^{* * *} \\
(0.173)\end{array}$ & $\begin{array}{c}4.045^{\star * *} \\
(0.659)\end{array}$ & $\begin{array}{l}4.164^{* *} \\
(1.692)\end{array}$ & $\begin{array}{c}2.682 \\
(1.616)\end{array}$ & $\begin{array}{l}2.323^{\star *} \\
(0.809)\end{array}$ & $\begin{array}{c}1.638 \\
(1.024)\end{array}$ \\
\hline $\begin{array}{l}\text { Observations } \\
\text { Adjusted R-squared } \\
\text { Pred. difference relative to baseline (Reciprocal) }\end{array}$ & $\begin{array}{c}299 \\
0.082 \\
16.98 \%\end{array}$ & $\begin{array}{c}299 \\
0.079 \\
17.15 \%\end{array}$ & $\begin{array}{c}299 \\
0.076 \\
17.56 \%\end{array}$ & $\begin{array}{c}299 \\
0.073 \\
17.61 \% \\
\end{array}$ & $\begin{array}{c}258 \\
0.083 \\
18.51 \%\end{array}$ & $\begin{array}{c}295 \\
0.465 \\
6.49 \% \\
\end{array}$ & $\begin{array}{c}254 \\
0.478 \\
7.33 \% \\
\end{array}$ \\
\hline
\end{tabular}

Table 4 Models of customer perceived value (Experiment 1)

***, ${ }^{* *}$ and $*$ denote significance at the $1 \%, 5 \%$ and $10 \%$ levels, respectively (two-tailed tests). Parentheses contain robust standard errors, clustered by meal and day.

\subsection{Experiment 2: The effect of operational transparency on customer perceptions}

Experiment 1 demonstrated that operational transparency that allows customers and employees to see one another can improve both objective performance and perceived service value. In order to examine whether the perceived and objective differences in performance evaluations were distinct effects, we conducted a second field experiment in a separate dining hall that serves a non-overlapping group of customers, drawn from a broader population. The dining hall used for Experiment 2 was located in the same university in the Northeastern United States.

3.2.1. Participants 48 participants ( $45.8 \%$ female; $\left.M_{a g e}=32.08, S D=10.11\right)$ responded to recruiting advertisements attached to all made-to-order sandwiches prepared by the dining hall's sandwich station. As such, the experiment targeted customers who had purchased a sandwich during the day of recruitment. The advertisement invited customers to access an online link to enroll in the experiment that afternoon, in exchange for a free, custom-made sandwich the following day. 


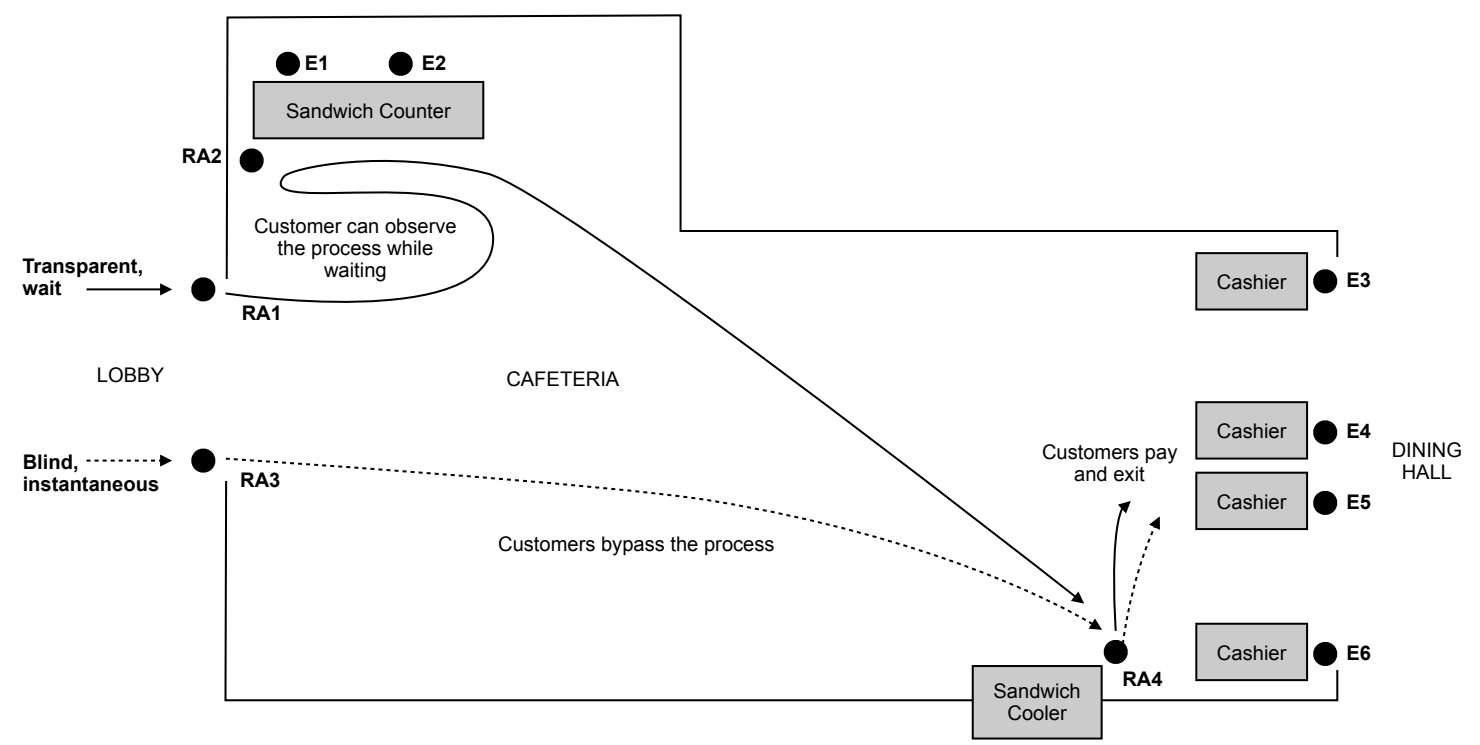

Figure 3 Layout of the dining hall and customer flow during field experiment (Experiment 2)

\begin{tabular}{l|c|c|c|c|c|c|c|c|c}
\hline & \multicolumn{3}{|c|}{ Blind } & \multicolumn{2}{c|}{ Transparent } & \multicolumn{3}{c}{ All } \\
\hline & $n$ & Mean & Std. Dev. & $n$ & Mean & Std. Dev. & $n$ & Mean & Std. Dev. \\
\hline & 23 & 5.85 & 1.18 & 25 & 5.79 & 1.08 & 48 & 5.82 & 1.12 \\
Perceived value & 23 & 6.12 & 1.13 & 25 & 5.52 & 1.08 & 48 & 5.81 & 1.13 \\
$\quad$ Initial perceived value & 23 & -0.27 & 0.53 & 25 & 0.27 & 0.70 & 48 & 0.01 & 0.68 \\
Perceived value difference & 23 & 5.57 & 1.31 & 24 & 5.54 & 1.72 & 47 & 5.55 & 1.52 \\
Food satisfaction & 23 & 6.26 & 1.01 & 25 & 6.20 & 0.87 & 48 & 6.23 & 0.93 \\
Initial food satisfaction & 23 & -0.70 & 1.61 & 24 & -0.63 & 1.86 & 47 & -0.66 & 1.72 \\
Food satisfaction difference & 23 & 6.61 & 1.27 & 25 & 6.68 & 1.25 & 48 & 6.65 & 1.25 \\
Sandwich complexity & 23 & 0.72 & 1.20 & 25 & 3.16 & 4.37 & 48 & 1.99 & 3.46 \\
Perceived wait (minutes) & 23 & 29.70 & 19.74 & 25 & 34.16 & 18.52 & 48 & 32.02 & 19.05 \\
Time allotted (minutes) & 23 & 32.96 & 11.17 & 25 & 31.28 & 9.17 & 48 & 32.08 & 10.11 \\
Age & 23 & $47.8 \%$ & 0.67 & 25 & $44.0 \%$ & 0.58 & 48 & $45.8 \%$ & 0.62 \\
Female pct. & & & & & & & & & \\
Education & 23 & $4.3 \%$ & 0.21 & 25 & $0.0 \%$ & 0.00 & 48 & $2.1 \%$ & 0.14 \\
High school pct. & 23 & $4.3 \%$ & 0.21 & 25 & $4.0 \%$ & 0.20 & 48 & $4.2 \%$ & 0.20 \\
Some college pct. & 23 & $47.8 \%$ & 0.51 & 25 & $60.0 \%$ & 0.50 & 48 & $54.2 \%$ & 0.50 \\
4-year college degree pct. & 23 & $39.1 \%$ & 0.50 & 25 & $28.0 \%$ & 0.46 & 48 & $33.3 \%$ & 0.48 \\
Masters degree pct. & 23 & $4.3 \%$ & 0.21 & 25 & $8.0 \%$ & 0.28 & 48 & $6.3 \%$ & 0.24 \\
Doctorate or professional degree pct. & & & & & & & & & \\
Ethnicity & 23 & $13.0 \%$ & 0.34 & 25 & $20.0 \%$ & 0.41 & 48 & $16.7 \%$ & 0.38 \\
Asian pct. & 23 & $78.3 \%$ & 0.42 & 25 & $60.0 \%$ & 0.50 & 48 & $68.8 \%$ & 0.47 \\
Caucasian pct. & 23 & $0.0 \%$ & 0.00 & 25 & $4.0 \%$ & 0.20 & 48 & $2.1 \%$ & 0.14 \\
Hispanic pct. & 23 & $8.7 \%$ & 0.29 & 25 & $16.0 \%$ & 0.37 & 48 & $12.5 \%$ & 0.33 \\
Other pct. & & & & & & & & & \\
& & & & & & & & & \\
\end{tabular}

Table 5 Summary statistics (Experiment 2)

3.2.2. Design and procedure Upon enrollment, participants rated their satisfaction with the sandwich they ordered and their perceptions of the value of the sandwich station (Sweeney and Soutar 2001) $(\alpha=0.86)$, using the same measures as Experiment 1 . They also placed an order 
for the sandwich they would receive for lunch during the following day. The online order form replicated all options available for made-to-order sandwiches. Importantly, during the time of the experiment, this dining hall was in the midst of introducing a process to allow customers to preorder sandwiches, but the offering had not yet gained popularity. Our experiment thus represented the first time this sample of customers received pre-ordered sandwiches from this facility. The madeto-order sandwich experience, which we use to establish baseline satisfaction and value perception measures for each participant, is therefore a relevant comparison.

Participants were randomly assigned to one of two conditions, and upon pre-ordering their sandwich, were given instructions to bring their participant ID number and meet a research assistant wearing a red or yellow t-shirt, that corresponded to their condition. The colors of research assistant t-shirts and the roles played by each research assistant were counterbalanced across conditions over the multiple days during which this experiment was run. Participants in the "blind" condition met a research assistant at the door to the cafeteria who escorted them directly to a cooler to pick up the sandwich they had pre-ordered, which had been made to their specifications before their arrival, and indexed by participant ID number. Those in the transparent condition met a research assistant who escorted them to the sandwich station queue, where they waited in view of the sandwich-making process. When the participant reached the front of the queue, and before the participant interacted with the chef, a second research assistant met the participant and escorted them to the same cooler described above to pick up their pre-made sandwich. At the conclusion of the lunch period, which lasted from 11:30 am - 2:00 pm, participants in both conditions were emailed a link to a second survey that asked them to evaluate their satisfaction with the food and their perceptions of the value of the sandwich station (Sweeney and Soutar 2001) ( $\alpha=0.88$ ), using the same measures as above. ${ }^{9}$

3.2.3. Dependent measures Perceived value and food satisfaction responses were differenced against the initial day's responses to create normalized metrics for each participant. Positive differences represent an increase in the measures, whereas negative values represent a decrease. Perceived value in the blind condition fell from an average of $(M=6.12, S D=1.13)$ to an average of $(M=5.85, S D=1.18)$, a decrease of $(M=-0.27, S D=0.53)$. In contrast, perceived value in the transparent condition increased from an average of $(M=5.52, S D=1.08)$ to an average of $(M=5.79, S D=1.08)$, an increase of $(M=0.27, S D=0.70)$. However, food satisfaction fell in both conditions, from an average of $(M=6.26, S D=1.01)$ to an average of $(M=5.57, S D=1.31)$ in the blind condition, a decrease of $(M=-0.70, S D=1.61)$, and from an average of $(M=$

\footnotetext{
${ }^{9}$ We note that email addresses were stored separately from survey responses and were deleted at the conclusion of the study, to protect the anonymity of participant responses.
} 


\begin{tabular}{|c|c|c|c|c|c|c|c|c|}
\hline & (1) & (2) & (3) & (4) & (5) & (6) & $(7)$ & (8) \\
\hline & $\begin{array}{c}\text { Perceived } \\
\text { value change }\end{array}$ & $\begin{array}{c}\text { Perceived } \\
\text { value change }\end{array}$ & $\begin{array}{c}\text { Perceived } \\
\text { value change }\end{array}$ & $\begin{array}{c}\text { Perceived } \\
\text { value change }\end{array}$ & $\begin{array}{c}\text { Perceived } \\
\text { value change }\end{array}$ & $\begin{array}{c}\text { Perceived } \\
\text { value change }\end{array}$ & $\begin{array}{c}\text { Perceived } \\
\text { value change }\end{array}$ & $\begin{array}{c}\text { Food } \\
\text { satisfaction } \\
\text { change }\end{array}$ \\
\hline 1. Transparency condition & $\begin{array}{c}0.545^{\star * *} \\
(0.178)\end{array}$ & $\begin{array}{c}0.465^{\star * *} \\
(0.162)\end{array}$ & $\begin{array}{c}0.531^{* * *} \\
(0.177)\end{array}$ & $\begin{array}{c}0.521^{* * *} \\
(0.184)\end{array}$ & $\begin{array}{c}0.544^{* * *} \\
(0.184)\end{array}$ & $\begin{array}{l}0.510^{* *} \\
(0.197)\end{array}$ & $\begin{array}{l}0.478^{* *} \\
(0.180)\end{array}$ & $\begin{array}{c}0.252 \\
(0.347)\end{array}$ \\
\hline 2. Initial perceived value & & $\begin{array}{c}-0.133^{*} \\
(0.0676)\end{array}$ & $\begin{array}{c}-0.123^{*} \\
(0.0701)\end{array}$ & $\begin{array}{c}-0.115 \\
(0.0747)\end{array}$ & $\begin{array}{c}-0.153^{*} \\
(0.0907)\end{array}$ & $\begin{array}{c}-0.0959 \\
(0.0866)\end{array}$ & $\begin{array}{l}-0.166^{* *} \\
(0.0781)\end{array}$ & \\
\hline 3. Perceived wait & & & $\begin{array}{l}-0.0222 \\
(0.0253)\end{array}$ & $\begin{array}{l}-0.0187 \\
(0.0222)\end{array}$ & $\begin{array}{l}-0.0263 \\
(0.0222)\end{array}$ & $\begin{array}{l}-0.00620 \\
(0.0311)\end{array}$ & $\begin{array}{c}0.0108 \\
(0.0285)\end{array}$ & $\begin{array}{c}0.0443 \\
(0.0377)\end{array}$ \\
\hline 4. Time allotted for lunch & & & $\begin{array}{c}-0.00117 \\
(0.00499)\end{array}$ & $\begin{array}{c}-0.00172 \\
(0.00487)\end{array}$ & $\begin{array}{l}0.000710 \\
(0.00509)\end{array}$ & $\begin{array}{r}-0.000822 \\
(0.00642)\end{array}$ & $\begin{array}{c}-0.00296 \\
(0.00593)\end{array}$ & $\begin{array}{r}-0.00732 \\
(0.0121)\end{array}$ \\
\hline 5. Complexity & & & & $\begin{array}{c}0.124^{*} \\
(0.0658)\end{array}$ & $\begin{array}{c}0.124^{*} \\
(0.0675)\end{array}$ & $\begin{array}{c}0.180^{* *} \\
(0.0822)\end{array}$ & $\begin{array}{c}0.148^{*} \\
(0.0796)\end{array}$ & $\begin{array}{l}-0.185 \\
(0.143)\end{array}$ \\
\hline 6. Perceived freshness & & & & & $\begin{array}{c}0.121^{*} \\
(0.0680)\end{array}$ & $\begin{array}{c}0.0617 \\
(0.0765)\end{array}$ & $\begin{array}{l}0.0876 \\
(0.111)\end{array}$ & $\begin{array}{c}0.851^{* * *} \\
(0.140)\end{array}$ \\
\hline 7. Age & & & & & & $\begin{array}{c}-0.0138 \\
(0.0105)\end{array}$ & $\begin{array}{c}-0.0172 \\
(0.0123)\end{array}$ & $\begin{array}{c}-0.0679^{* * *} \\
(0.0236)\end{array}$ \\
\hline 8. Female indicator & & & & & & $\begin{array}{l}0.315^{\star *} \\
(0.145)\end{array}$ & $\begin{array}{l}0.321^{* *} \\
(0.139)\end{array}$ & $\begin{array}{c}-0.00133 \\
(0.348)\end{array}$ \\
\hline 9. Food satisfaction change & & & & & & & $\begin{array}{c}-0.0787 \\
(0.0930)\end{array}$ & \\
\hline 10. Initial food satisfaction & & & & & & & $\begin{array}{c}0.155 \\
(0.157)\end{array}$ & $\begin{array}{c}-1.124^{\star \star *} \\
(0.176)\end{array}$ \\
\hline Constant & $\begin{array}{c}-0.272^{\star *} \\
(0.110)\end{array}$ & $\begin{array}{c}0.545 \\
(0.412)\end{array}$ & $\begin{array}{c}0.530 \\
(0.488)\end{array}$ & $\begin{array}{c}-0.321 \\
(0.719)\end{array}$ & $\begin{array}{l}-0.823 \\
(0.801)\end{array}$ & $\begin{array}{l}-0.766 \\
(0.952)\end{array}$ & $\begin{array}{c}-1.554 \\
(1.131)\end{array}$ & $\begin{array}{l}5.023^{* *} \\
(2.005)\end{array}$ \\
\hline $\begin{array}{l}\text { Education controls } \\
\text { Ethnicity controls } \\
\text { Observations } \\
\text { Adjusted R-squared }\end{array}$ & $\begin{array}{c}\text { No } \\
\text { No } \\
48 \\
0.148\end{array}$ & $\begin{array}{c}\text { No } \\
\text { No } \\
48 \\
0.177\end{array}$ & $\begin{array}{c}\text { No } \\
\text { No } \\
48 \\
0.152\end{array}$ & $\begin{array}{c}\text { No } \\
\text { No } \\
48 \\
0.189\end{array}$ & $\begin{array}{c}\text { No } \\
\text { No } \\
48 \\
0.242\end{array}$ & $\begin{array}{c}\text { Yes } \\
\text { Yes } \\
48 \\
0.292\end{array}$ & $\begin{array}{c}\text { Yes } \\
\text { Yes } \\
47 \\
0.375\end{array}$ & $\begin{array}{c}\text { Yes } \\
\text { Yes } \\
47 \\
0.677\end{array}$ \\
\hline
\end{tabular}

Table 6 Models of perceived value and food satisfaction changes (Experiment 2)

***, ${ }^{* *}$ and $*$ denote significance at the $1 \%, 5 \%$ and $10 \%$ levels, respectively (two-tailed tests). Parentheses contain robust standard errors. One participant did not complete the food satisfaction question on the second survey, resulting in the smaller sample size in Columns (6-7).

$6.20, S D=0.87)$ to an average of $(M=5.54, S D=1.72)$ in the transparent condition, a difference of $(M=-0.63, S D=1.86)$. Because of the differences in initial value perceptions among customers randomly assigned to the treatment and control conditions, we introduce controls for initial value perceptions and initial food satisfaction in our models, where appropriate.

3.2.4. Control variables We control for a handful of experiential and demographic factors that may have affected perceived value and food satisfaction. In addition to the dependent measures, participants were asked about their perceptions of the length of time they waited for their sandwich. As anticipated, participants in the transparent condition, who waited in the queue in view of the sandwich-making process, perceived their waits to be longer $(M=3.16$ minutes, $S D=4.37$ minutes $)$ than participants in the control condition $(M=0.72$ minutes, $S D=1.20$ minutes). We also controlled for the time (in minutes) each customer reported allocating for lunch, 
and the complexity of their order, measured as the number of toppings they requested on their pre-made sandwich. To control for the possibility that participants in the transparent condition may have been more likely to infer that their sandwiches were freshly made, we controlled for subjects' perceptions of the freshness of the sandwich. Perceptions of freshness were not significantly different between the transparent $(M=5.16, S D=1.72)$ and blind conditions $(M=5.48, S D=$ $1.31 ; t(46)=0.71, p=N S)$. We also introduced a vector of demographic controls, including age, gender, ethnicity, and education.

3.2.5. Analysis and results We model changes in perceived value and food satisfaction, $Y$, as a linear function of whether the customer was randomly assigned to the transparency condition, TRANSPARENCY, initial period value perceptions and satisfaction, INITIAL, and a series of experiential (WAIT, ALLOTTED, COM PLEXITY, FRESHNESS) and demographic controls.

$$
\begin{aligned}
Y=f\left(\gamma_{0}+\gamma_{1} T R A N S P A R E N C Y+\gamma_{2} I N I T I A L+\gamma_{3} W A I T+\right. \\
\left.\gamma_{4} A L L O T T E D+\gamma_{5} C O M P L E X I T Y+\gamma_{6} F R E S H N E S S+\gamma_{7} X+\epsilon\right)
\end{aligned}
$$

Consistent with Experiment 1, Table (6), Column (1) shows that relative to their initial perceptions, participants in the transparent condition, who were able to observe the sandwich-making process, perceived the service to be more valuable on average than participants who were not able to observe the process $\left(\gamma_{1}=0.545, p<0.01\right)$. This is somewhat surprising, given that participants in the transparent condition were not observing their own sandwiches being prepared. It is also counterintuitive in light of the fact that participants in the transparent condition reported waiting for their sandwich more than four times longer on average than participants in the blind condition. Columns (2-6) demonstrate that this effect is robust to controls for initial value perceptions, perceived waiting time, time allotted for lunch, complexity of the sandwich order, perceived freshness, and demographic controls $\left(\gamma_{1}=0.510, p<0.05\right)$. As seen in Experiment 1 , Column $(7)$ shows that the increase in perceived value engendered by transparency is robust to controlling for the customer's satisfaction with the food they received $\left(\gamma_{1}=0.478, p<0.05\right)$. However, since the sandwiches in this study were pre-made, transparency could not have influenced the behavior of the chefs, and therefore did not result in an improvement in objective service quality $\left(\gamma_{1}=0.252, p=\right.$ $N S$ ). This pattern of results offers converging evidence that perceived and objective performance may be separately influenced by the introduction of operational transparency.

Experiments 1 and 2 provided field evidence that introducing operational transparency can generate positive outcomes for both consumers and employees. What factors might have led to these improvements? Motivated both by prior research and field observations, we hypothesize that customers who observe employees at work, relative to those who never see them, should perceive 
greater effort and experience deeper feelings of appreciation. Similarly, for chefs, we hypothesize that those who observe the grateful beneficiaries of their work may feel more appreciated, and in turn, become more satisfied and willing to exert more effort. In fact, when we debriefed the kitchen staff at the conclusion of Experiment 1, one chef volunteered the following explanation: "When [the customers] can see the work we're doing for them, they appreciate it, and I appreciate that. It makes me want to improve." Experiments 3A, 3B and 4 turned to laboratory experiments in order to test these two hypotheses.

\subsection{Experiment 3A: Mechanisms underlying the effects on customers}

In Experiment 3A, we test whether appreciation and perceived effort serve as an underlying mechanism for the pattern of effects among consumers. This customer-side theoretical account is consistent with prior research conducted in non-face-to-face service settings (Buell and Norton 2011).

3.3.1. Participants 272 participants $\left(62.5 \%\right.$ male; $\left.M_{a g e}=31.48, S D=10.11\right)$ completed this experiment on the Amazon Mechanical Turk platform in exchange for 50 cents. Participants were asked to assume the role of a customer as they watched a video of a service interaction that took place at a cafeteria sandwich counter. For analysis, we retained data from the 254 participants who watched at least the first minute of the assigned two-minute video ( $61.4 \%$ male; $M_{a g e}=31.80$, $S D=10.24$ ), as participants who watched for less than one minute failed to fully observe the experimental manipulation.

3.3.2. Design and procedure Participants were randomly assigned to watch one of three videos portraying a service interaction at a cafeteria sandwich counter, viewed from the customer's perspective. All videos were filmed using a head-mounted camera worn by an actual customer. Thus, participants could vicariously experience what the customer in the video was experiencing. Each video represented a service design employing a different level of visual access to the chef and process: 1) the customer handed the order to a non-chef employee, who relayed it to the chef, who made the sandwich out of the customer's view (customer observes neither the chef nor the process), 2) the customer handed the order directly to the chef, who made the sandwich out of the customer's view (customer observes chef outside the process), or 3) the customer handed the order to the chef, who made the sandwich in full view of the customer (customer observes chef throughout the process) (Figure 4A). This final condition most closely mirrors the reciprocal transparency condition from Experiment 1. To ensure equivalent outcome quality perceptions across conditions, all participants were shown the same image of a sandwich, pickle, and bag of chips as the outcome of the service, before being directed to a series of questions about their experience. 
A. Customer perspective (Experiments 3A, 3B)

B. Employee perspective (Experiment 4)
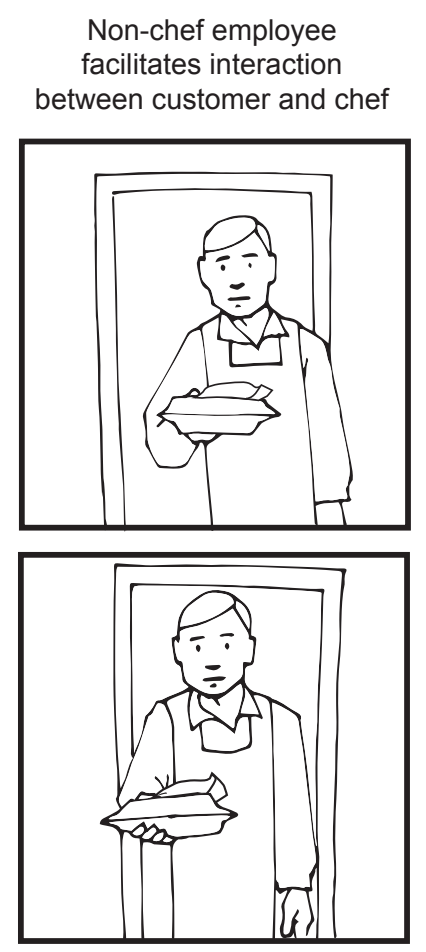

Customer and chef observe each other outside of the process
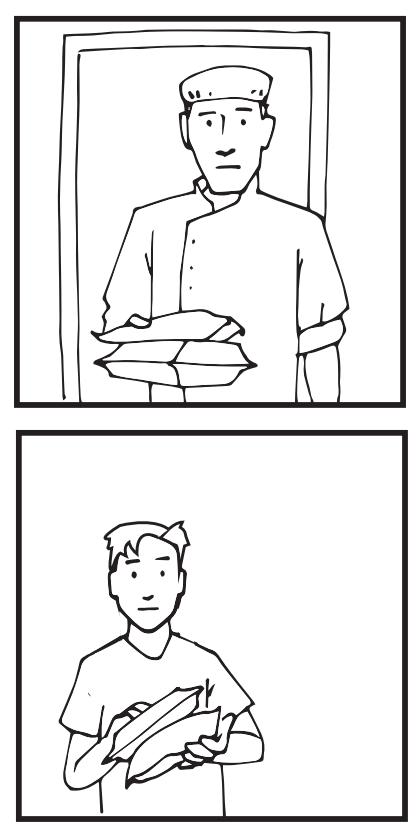

Customer and chef observe each other throughout the process
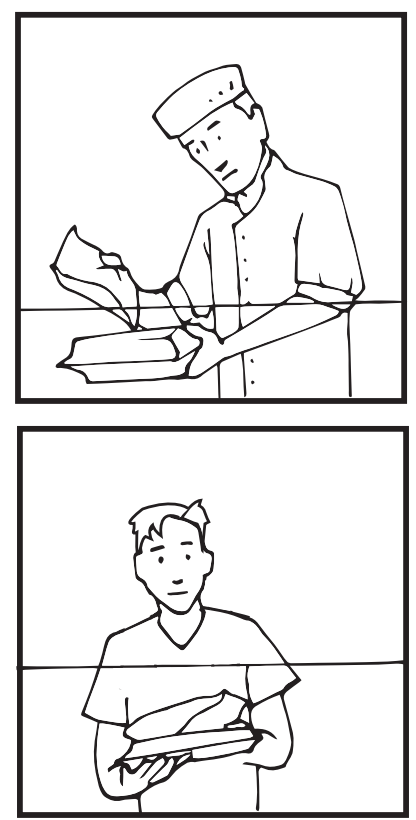

Figure 4 Visual depictions of experimental conditions (Experiments 3-4)

3.3.3. Dependent measures Along with the perceived value scale $(\alpha=0.94)$ (Sweeney and Soutar 2001), we measured perceived effort using an adapted four-item scale: "How much effort do you think the chef put in?", "How much expertise do you think the chef has?", "How much experience do you think the chef has?", and "How thorough was the chef in delivering your food?" $(\alpha=0.91)$ (Buell and Norton 2011). We also measured feelings of appreciation using an adapted 3-item scale: "How positively do you feel toward the chef?", "How appreciative do you feel toward the chef?", and "How grateful do you feel toward the chef?" $(\alpha=0.95)$ (Bartlett and DeSteno 2006). We conducted a confirmatory factor analysis, which led us to drop the thoroughness item from the effort scale, as it loaded more strongly on the appreciation factor $\left(R C_{a p p}=0.702\right)$ than the effort factor $\left(R C_{\text {eft }}=0.379\right)$. Despite dropping the thoroughness item, the three-item effort scale retained strong internal reliability $(\alpha=0.91)$.

3.3.4. Analysis and results A univariate ANOVA suggests that there was a significant difference in perceived value across conditions, $F(2,253)=13.89, P<0.01$. More specifically, participants who observed the chef throughout the process reported higher perceived value $(M=5.68$, $S D=0.99)$ than those who observed the chef outside the process $(M=4.79, S D=1.51), t(173)=$ 4.59, $P<0.01$; and those who observed neither the chef nor the process $(M=4.77, S D=1.36)$, $t(168)=5.02, P<0.01$. There was no significant difference between participants in the two latter conditions, $t(161)=0.11, P=N S$. Perceived effort and appreciation measures followed a similar 
pattern, with significant differences across conditions, $F(2,253)=9.99, P<0.01$; and $F(2,253)=$ 17.51, $P<0.01$, respectively. Participants observing the chef throughout the process perceived more effort $(M=4.95, S D=1.24)$ and appreciated the provider more $(M=5.64, S D=1.12)$ than participants who observed the chef outside the process $(M=4.34, S D=1.22 ; t(173)=3.25 ; P<0.01)$, $(M=4.62, S D=1.39 ; t(173)=5.38, P<0.01)$, and participants who saw neither the chef nor the process $(M=4.14, S D=1.26 ; t(168)=4.21, P<0.01),(M=4.62, S D=1.47 ; t(168)=5.18$, $P<0.01)$, respectively. Similar to perceived value, there were no significant differences in perceived effort and appreciation between participants who observed the chef outside the process and those who observed neither the chef nor the process, $t(161)=1.06, P=N S$; and $t(161)=0.03, P=N S$, respectively. Consistent with the results in Experiments 1 and 2, greater transparency led to higher customer perceived value.

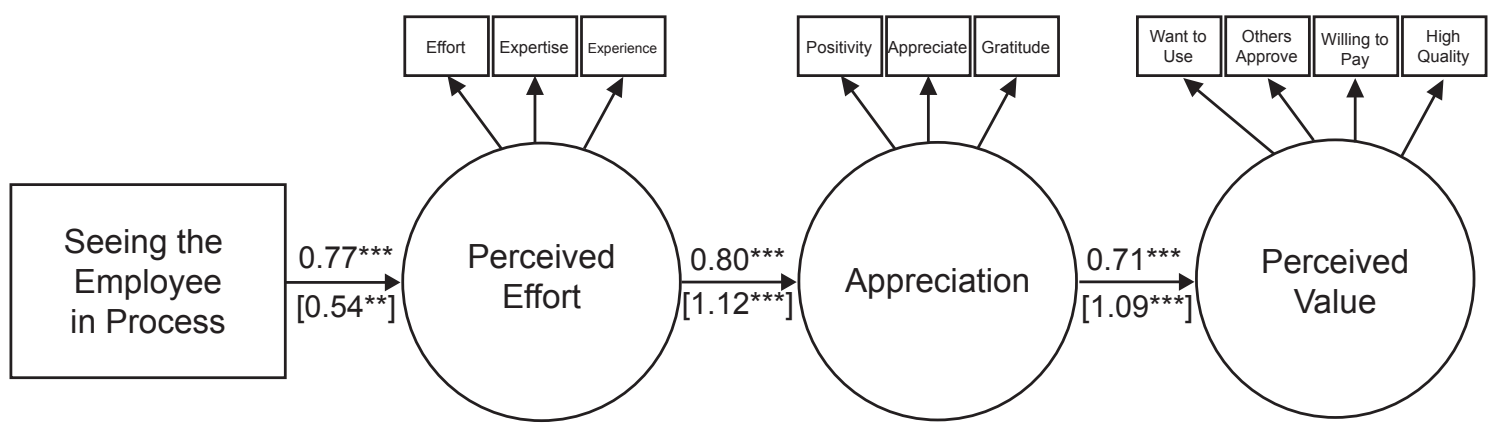

Figure 5 Customer path analysis (Experiments 3A and 3B)

Standardized beta coefficients displayed for Experiments 3A and 3B. Coefficients for Experiment 3B are shown in brackets. Seeing the employee in process is compared with the baseline condition, during which customers and employees could not observe one another. ${ }^{*}, * *$, and ${ }^{* *}$ indicate significance at the $10 \%, 5 \%$, and $1 \%$ levels, respectively.

To test the theory that operational transparency increases perceptions of effort, which lead the customer to feel more appreciative of the employee and thus perceive the service as more valuable, we used structural equation modeling to conduct a path analysis using the perceived effort, appreciation, and perceived value measures. Given that our results suggest that observing the chef throughout the process is what triggers improved perceptions, we modeled that condition against the baseline condition, during which the customer and chef could not see one another. As noted in (Figure 5 - coefficients without brackets), observing the chef throughout the process is positively associated with perceived effort (standardized regression coefficient $\beta=0.77, P<$ 0.01 ), which in turn is positively associated with appreciation (standardized regression coefficient $\beta=0.80, P<0.01$ ), which has a positive association with perceived value (standardized regression coefficient $\beta=0.71, P<0.01)$. The model exhibits a strong fit, with a high Comparative Fit 
Index $(C F I=0.925)$, and a low Root Mean Squared Error of Approximation $(R M S E A=0.141$, $P<0.01)$. These results are consistent with the theory that operational transparency enhances perceptions of service value by increasing perceptions of effort, and in turn, appreciation.

\subsection{Experiment 3B: Generalizability of mechanisms underlying customer effects}

Given the prevalence of open kitchens in Western society, one possibility is that customers in the United States have become socialized to perceive open kitchens more favorably. In Experiment 3B, we test the extent to which the patterns we have thus far observed only in participants based in the United States generalize across cultures.

3.4.1. Participants 91 participants $\left(55.1 \%\right.$ female; $\left.M_{\text {age }}=33.44, S D=12.98\right)$ were recruited from isolated, rural areas in Kenya by an independent research center headed by academic institutions based in the United States and Switzerland. Participants had little to no exposure to Western media and culture. ${ }^{10}$

3.4.2. Design and procedure A team of researchers and translators prepared versions of survey materials based on those used in Experiment 3A, travelled to these remote regions, and presented the materials to participants through iPads. Researchers helped familiarize participants with the materials, and at times, assisted with entering responses for the participants. ${ }^{11}$

As this study examined the generalizability of the mechanisms found in Experiment 3A, the procedure and design paralleled those in the earlier study. Participants were thus asked to assume the role of a customer and were randomly assigned to one of three conditions: blind, chef transparency, and reciprocal transparency. The same videos were used as in Experiment 3A.

3.4.3. Dependent measures We used the same instruments as in Experiment $3 \mathrm{~A}$ to measure perceived effort $(\alpha=0.85)$, appreciation $(\alpha=0.81)$, and perceived value $(\alpha=0.75)$.

3.4.4. Results and analysis Although this population was vastly different from those included in the previous studies, the general positive effects of transparency still emerged. Participants who observed the chef throughout the process reported higher perceived value $(M=6.11$, $S D=1.30)$ than those who observed the chef outside the process $(M=5.54, S D=1.62)$; and those who observed neither the chef nor the process $(M=5.38, S D=1.72)$. There was a marginally significant difference between participants who observed the chef throughout the process and those who saw neither the chef nor the process, $t(61)=1.91, P=0.06$. Perceived effort and appreciation

\footnotetext{
${ }^{10}$ The demographic information was collected from 107 respondents, and 17 individuals were unable to fully complete the main part of the study due to lack of comprehension of survey items or issues with the survey response system.

${ }^{11}$ Volunteers were compensated on average $\$ 3.17$ for their participation in sessions that included this study and another unrelated study. This rate was chosen so as to be commensurate with average daily earnings in the region, ensuring that participants were properly compensated for their time, but not at levels so high as to become coercive.
} 
measures followed a similar pattern, with significant differences in impact on consumers between full versus no transparency. Participants observing the chef throughout the process perceived more effort $(M=6.66, S D=0.83)$ and appreciated the provider more $(M=6.51, S D=0.95)$ than participants who saw neither the chef nor the process $(M=5.97, S D=1.70 ; t(61)=1.99, P=0.05)$, $(M=5.75, S D=1.79 ; t(61)=2.08, P<0.05)$, respectively. For these items, there were no significant differences between those who observed the chef throughout the process and those who observed the chef outside the process, $(M=6.16, S D=1.21 ; t(57)=1.45, P=N S)$, and $(M=5.96$, $S D=1.60 ; t(57)=1.60, P=N S)$, respectively. Similar to perceived value, there were no significant differences in perceived effort and appreciation between participants who observed the chef outside the process and those who observed neither the chef nor the process, $t(58)=0.70, P=N S$; and $t(58)=0.49, P=N S$, respectively.

Furthermore, we replicated the path analysis from Experiment 3A, and observe a similar pattern of effects (Figure 5 - coefficients in brackets). Observing the chef throughout the process is positively associated with perceived effort (standardized regression coefficient $\beta=0.54, P<$ 0.05), Perceived effort, in turn, is positively associated with appreciation (standardized regression coefficient $\beta=1.12, P<0.01$ ), and appreciation is positively associated with perceived value (standardized regression coefficient $\beta=1.09, P<0.01$ ). Again, the model exhibited a strong fit, with a Comparative Fit Index $(C F I=0.855)$, and a Root Mean Squared Error of Approximation ( $R M S E A=0.163, P<0.01)$. These results provide converging evidence that transparency offers benefits across cultures, as customers can perceive transparent processes to be more effortful, and experience both increased appreciation for service providers, and higher value perceptions of the service.

\subsection{Experiment 4: Mechanisms underlying the effects on employees}

The results from Experiments $3 \mathrm{~A}$ and $3 \mathrm{~B}$ demonstrate one mechanism underlying the effects of operational transparency on customer perceptions of service, but what accounts for the objective improvement in employee service performance? We test three possible mechanisms: perceptions of customers' appreciation, perceptions of the work's impact, and perceptions of monitoring. First, we tested whether appreciation and effort would mirror the link that we identified for customers: whether employees would feel more appreciated after seeing customers and thus be more willing to exert greater effort. If so, this could help account for the finding in Experiment 1, in which chefs made higher quality food when they could see their customers. A second explanation for this pattern of effects is that seeing the beneficiaries of one's efforts may make the work feel more impactful. Theory suggests that the relational architecture of a job increases the motivation to make a prosocial difference by connecting employees to the impact they are having on the beneficiaries of 
their work (Grant 2007) and prior research has shown that asynchronous contact with beneficiaries bolsters motivation and persistence (Grant et al. 2007). We sought to test whether the same pattern of results exist in synchronous settings, when the customer is present while the work is being performed. Third, through the design of the experiment, we further sought to disentangle the effect of reciprocal transparency on effort from the effects of monitoring. To the extent that a customer could be perceived as an on-site manager when they are able to observe employees, the feeling of being monitored, engendered by transparency to the customer, may intensify employee effort. Mirroring our earlier experiments, we utilize two transparency treatments, which allow us to separately evaluate the effects of transparency when the customer can and cannot observe the employee's efforts.

3.5.1. Participants We recruited 599 participants from Amazon Mechanical Turk (64.1\% male; $\left.M_{\text {age }}=33.56, S D=11.55\right)$ and asked them to assume the role of a chef employee while watching the video of a service interaction. All videos mirrored those described in Experiments $3 \mathrm{~A}$ and $3 \mathrm{~B}$, but from the chef employee's perspective. We ensured the quality of participant data by only retaining data from those who viewed at least the first minute of the two-minute video and those who correctly answered a free response question about the role they were assuming in the experiment. These exclusion criteria resulted in a sample of 557 participants $(63.4 \%$ male; $M_{a g e}=33.74, S D=11.67$ ), which we report for our primary analysis. We also report statistics from a subset of this sample who reported prior work experiences in food service $(N=180,58.3 \%$ male; $M_{\text {age }}=33.01, S D=10.22$ ), and we note that the pattern of results generalizes across samples with and without prior industry experience (Table 7).

3.5.2. Design and procedure Mirroring Experiments $3 \mathrm{~A}$ and $3 \mathrm{~B}$, participants were randomly assigned to watch one of three videos portraying a service interaction at a cafeteria sandwich counter, this time viewed from the employee's perspective. All videos were captured with a headmounted camera worn by an actual employee. Thus, participants could vicariously experience what the employee in the video was experiencing. Each video represented a service design employing a different degree of visual access to the customer, during various phases of the process: 1) a non-chef employee serves as the intermediary between the chef and the customer (chef does not observe customer), 2) the customer hands the order directly to the chef, who makes the sandwich out of the customer's view (chef observes customer outside the process), or 3) the customer hands the order to the chef, who makes the sandwich in full view of the customer (chef observes customer throughout the process) (Figure 4B). Importantly, this experimental design enables us to disentangle the incremental effect of monitoring from the effect of reciprocal transparency. The type of 
transparency represented in the third condition is concurrent with the chef's effort, providing the customer with an opportunity to monitor the chef's performance.

Prior to watching the video, participants read a description of the service design. Participants in the chef does not observe customer condition read, "You work as a chef in the deli section of a cafeteria that features various stations. Customers place their orders by filling out an order sheet and handing it to one of the staff. The staff brings the order sheet to the kitchen, and you make the sandwich in the kitchen, where customers do not have full view of the sandwich-making process. After you finish making the sandwich, you hand the finished product with complimentary chips and a pickle spear to the same staff, who steps out of the kitchen to deliver to customers. Throughout the entire process, you do not have any opportunity to see your customer." Participants in the chef observes customer outside the process condition read, "You work as a chef in the deli section of a cafeteria that features various stations. Customers place their orders by filling out an order sheet and handing it to you. You make the sandwich in the kitchen, where customers do not have full view of the sandwich-making process. After you finish making the sandwich, you step out of the kitchen and hand them the finished product with complimentary chips and a pickle spear. You have an opportunity to see your customer in the beginning when they place their order and in the end when they receive their order." Participants in the chef observes customer throughout the process condition read, "You work as a chef in the deli section of a cafeteria that features various stations. Customers place their orders by filling out an order sheet and handing it to you. You make the sandwich behind the glass window where they have full view of the sandwich-making process. After you finish making the sandwich, you hand them the finished product with complimentary chips and a pickle spear. Throughout the entire process, you have an opportunity to see your customer."

After reading the description and watching the video, in order to ensure equivalent outcome quality perceptions across conditions, all participants were shown the same image of a sandwich, pickle, and bag of chips as the outcome of the service, before being directed to a series of questions about their experience.

3.5.3. Dependent measures We examined participants' intended effort after watching the video, measured as the mean of the responses to the following items: "When there's a job to be done, I devote all my energy to getting it done," "When I work, I do so with intensity," "I work at my full capacity in all of my job duties," "I strive as hard as I can to be successful in my work," and "When I work, I really exert myself to the fullest" ( $\alpha=0.952)$ (Brown and Leigh 1996), as well as perceived job satisfaction: "How satisfied are you with your job in general?"

To test whether perceived appreciation explained differences in intended effort and job satisfaction, we measured the degree to which participants assuming the role of the employees felt 
appreciated in their work: "How much positivity do you feel from the consumer?", "How appreciated do you feel by the consumer?", and "How much gratitude do you feel from the consumer?" $(\alpha=0.967)$ (Bartlett and DeSteno 2006).

To measure perceived impact and monitoring, we adapted items from Hochwarter et al. (2003) and Thoms et al. (2002). Perceived impact items included "The outcomes experienced by my customers depend on my success or failure.", "To what extent do the methods that you use to perform your job have an impact on your customers?," and "To what extent does your level of performance of your job have an impact on customers?" $(\alpha=0.848)$. Perceived monitoring items included, "I often have to explain why I do certain things at work", "Customers closely scrutinize my efforts at work", "To what extent do you have to justify the methods that you use in performing your job to your customers?," and "To what extent do you have to justify your effectiveness in performing your job to your customers?" $(\alpha=0.866)$.

Confirmatory factor analysis revealed strong factor loadings for each scale, with no excluded item factor loading exceeding $R C=0.348$ and no included item factor loading falling below $R C=0.699$.

3.5.4. Results and analysis A univariate ANOVA revealed significant differences in effort, $F(2,552)=5.78, P<0.01$, job satisfaction, $F(2,552)=4.98, P<0.01$, appreciation, $F(2,552)=$ 128.43, $P<0.01$, and monitoring, $F(2,552)=80.69, P<0.01$, across conditions, as well as a marginally significant difference in perceived impact of the work, $F(2,552)=2.67, P<0.10$.

Participants who experienced the two transparent conditions reported higher intended effort $(M=5.66, S D=1.05)$ and job satisfaction $(M=5.22, S D=1.40)$ than participants in the blind condition, $(M=5.31, S D=1.35), t(555)=3.31, P<0.01 ;$ and $(M=4.82, S D=1.58), t(555)=$ $3.06, P<0.01$, respectively. It is worth noting the differences in the patterns exhibited by customers (in Experiments 3A and 3B) and employees (in the present experiment). For customers, observing the chef in process enhances perceptions of value, although observing the chef outside the process does not. Participants adopting the employee's perspective are more willing to exert effort and are more satisfied with their jobs if they can see the customer in any capacity, either inside or outside the process.

More specifically, higher intended effort was reported by participants who observed the customer outside the process $(M=5.61, S D=1.04)$ and during the process $(M=5.70, S D=1.06)$ than by participants who did not observe the customer, $t(375)=2.37, P<0.05$; and $t(370)=3.10, P<0.01$, respectively. Higher job satisfaction was also reported by participants who observed the customer outside the process $(M=5.16, S D=1.45)$ and during the process $(M=5.28, S D=1.35)$ than by participants who did not observe the customer, $t(375)=2.18, P<0.05$; and $t(370)=3.01, P<0.01$, respectively. There was not a significant difference in perceived effort or job satisfaction between the transparent conditions, $t(363)=.087, P=N S$; and, $t(363)=.825, P=N S$, respectively. 


\begin{tabular}{l|c|c|c|c|c|c}
\hline & \multicolumn{2}{|c|}{$\begin{array}{c}\text { Chef observes customer } \\
\text { in process }\end{array}$} & $\begin{array}{c}\text { Chef observes customer } \\
\text { outside process }\end{array}$ & \multicolumn{2}{c}{$\begin{array}{c}\text { Chef does not observe } \\
\text { customer }\end{array}$} \\
\hline & $\begin{array}{c}\text { All } \\
(\mathrm{n}=180)\end{array}$ & $\begin{array}{c}\text { Food service } \\
(\mathrm{n}=52)\end{array}$ & $\begin{array}{c}\text { All } \\
(\mathrm{n}=185)\end{array}$ & $\begin{array}{c}\text { Food service } \\
(\mathrm{n}=64)\end{array}$ & $\begin{array}{c}\text { All } \\
(\mathrm{n}=192)\end{array}$ & $\begin{array}{c}\text { Food service } \\
(\mathrm{n}=64)\end{array}$ \\
\hline Effort & $5.70^{* * *}$ & $5.69^{*}$ & $5.61^{* *}$ & $5.70^{*}$ & 5.31 & 5.26 \\
Job satisfaction & $5.28^{* * *}$ & 5.15 & $5.16^{* *}$ & $5.34^{*}$ & 4.82 & 4.80 \\
Perceived appreciation & $5.10^{* * *}$ & $5.14^{* * *}$ & $5.08^{* * *}$ & $4.98^{* * *}$ & 3.02 & 3.05 \\
Perceived impact & $5.75^{* *}$ & $5.97^{* *}$ & 5.61 & 5.69 & 5.49 & 5.45 \\
Perceived monitoring & $4.34^{* * *}$ & $4.44^{* * *}$ & $2.98^{* * *}$ & $3.01^{* *}$ & 2.60 & 2.53 \\
\hline
\end{tabular}

Table 7 Effects of Transparency on Employee Effort, Job Satisfaction, Perceived Appreciation, Perceived Impact, and Perceived Monitoring (Experiment 4)

Independent-samples t-tests were conducted for each condition against the baseline control, in which the chef did not observe the customer. ${ }^{*}, * *$, and $* * *$ indicate significance at the $10 \%, 5 \%$, and $1 \%$ levels, respectively.

Broadly speaking, appreciation, monitoring, and impact followed similar patterns. Participants in the transparent conditions reported feeling more appreciated $(M=5.09, S D=1.24)$ than participants in the blind condition $(M=3.02, S D=1.77), t(555)=16.04, P<0.01$. Although there was not a significant difference in feelings of appreciation among customers in the transparent conditions, $t(363)=0.173, P=N S$, participants who saw the customer during $(M=5.10, S D=1.21)$ and outside the process $(M=5.08, S D=1.27)$ reported feeling more appreciated than participants who did not observe the customer, $t(370)=13.13, P<0.01$; and, $t(375)=12.90, P<0.01$, respectively.

Participants in the transparent conditions also reported feeling more monitored $(M=3.65, S D=$ 1.51) than participants in the blind condition, $(M=2.60, S D=1.42), t(555)=7.94, P<0.01$. Understandably, participants who experienced transparency during the service delivery process felt significantly more monitored $(M=4.34, S D=1.26)$ than participants who experienced transparency outside the process $(M=2.98, S D=1.42), t(362)=9.58, P<0.01$, who in turn, felt more monitored than participants who did not experience transparency $t(374)=2.60, P<0.01$.

Perceived impact followed a slightly different pattern. Although participants in the transparent conditions felt their work was marginally more impactful $(M=5.49, S D=1.24)$ than participants in the blind condition, $(M=5.68, S D=1.04), t(555)=1.93, P<0.10$, the effects were not consistent across conditions. In particular, relative to the participants who did not experience transparency, participants who were able to observe the customer during the process felt that their work was more impactful $(M=5.76, S D=1.00), t(370)=2.27, P<0.05$, whereas participants who observed the customer outside the process did not $(M=5.61, S D=1.07), t(375)=0.98, P=N S$.

The intuition provided by the chefs in the field and our findings from Experiment 1 suggest that seeing their customers makes employees feel more appreciated, and in turn, more satisfied with their jobs and more willing to exert effort. To test this theory, as well as the roles of perceived 


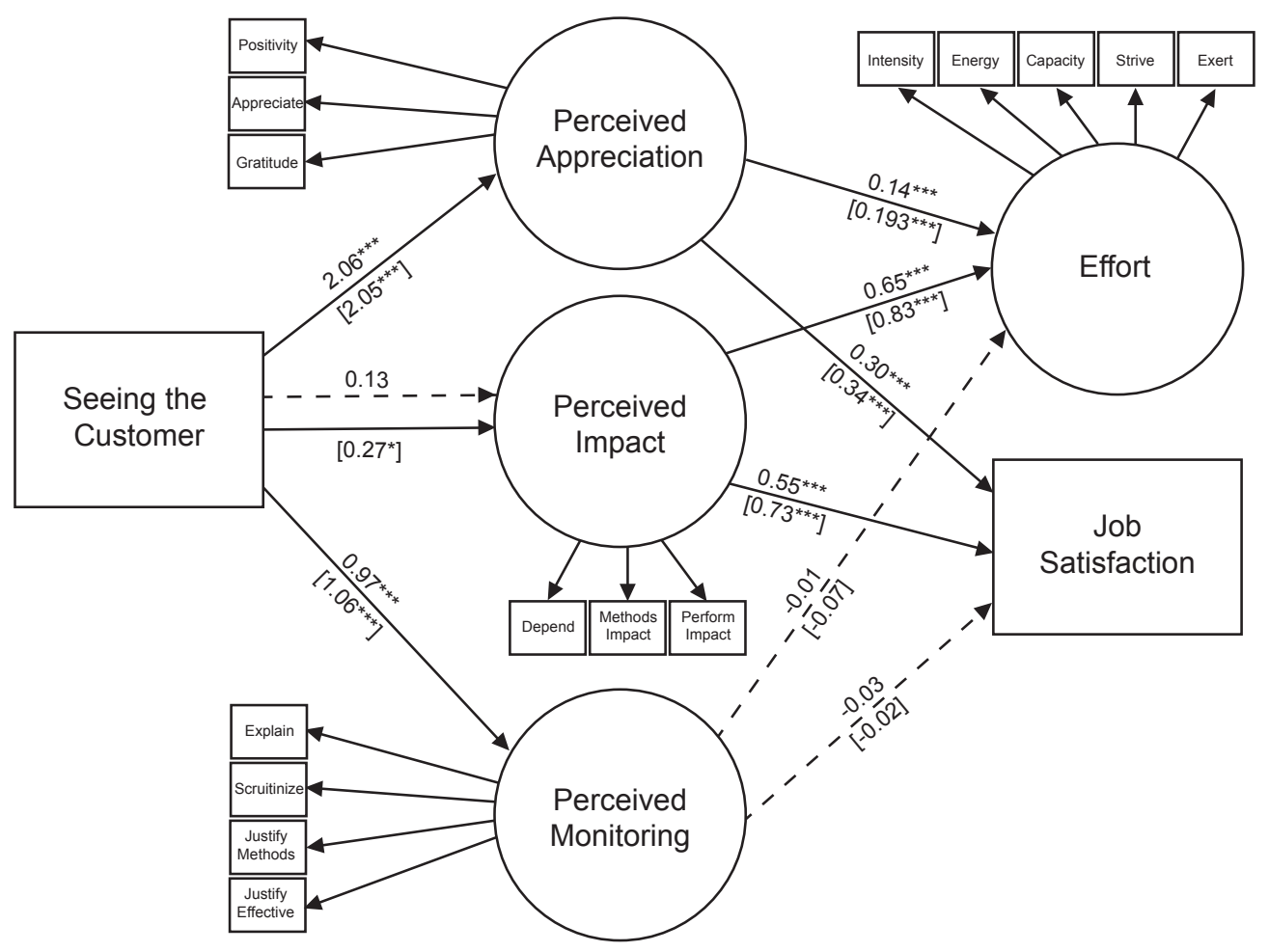

Figure 6 Employee path analysis (Experiment 4)

Standardized beta coefficients displayed for Experiment 4. Coefficients for all participants shown without brackets. Coefficients for participants with food service backgrounds shown in brackets. *, **, and *** indicate significance at the $10 \%, 5 \%$, and $1 \%$ levels, respectively.

impact and monitoring in promoting increased effort and job satisfaction, we again turned to structural equation modeling to conduct a path analysis. Our results suggest that seeing the customer causes employees to feel more appreciated (standardized regression coefficient $\beta=2.06, P<0.01$ ). Feeling appreciated, in turn, is separately and positively associated with willingness to exert effort (standardized regression coefficient $\beta=0.14, P<0.01$ ), and job satisfaction (standardized regression coefficient $\beta=0.30, P<0.01)$. Seeing the customer also increases perceptions of monitoring (standardized regression coefficient $\beta=0.97, P<0.01$ ). However, perceived monitoring is neither predictive of effort (standardized regression coefficient $\beta=-0.01, P=N S$ ) nor job satisfaction (standardized regression coefficient $\beta=-0.03, P=N S$ ). In our structural equation model, after accounting for the other factors, seeing the customer did not increase perceived impact (standardized regression coefficient $\beta=0.13, P=N S$ ) across the entire participant sample. However, among participants who had prior work experience in food service, perceived impact was marginally higher when the customer was visible (standardized regression coefficient $\beta=0.27, P<0.10$ ). Perceived impact, in turn, was positively associated with effort (standardized regression coefficient $\beta=0.65$, $P<0.01$ ) and job satisfaction (standardized regression coefficient $\beta=0.55, P<0.01$ ), for both 
samples. The model exhibited a strong fit, with a Comparative Fit Index $(C F I=0.969)$, and a Root Mean Squared Error of Approximation ( $R M S E A=0.063, P<0.01)$.

These results suggest that seeing the customer can cause employees to feel more gratitude, positivity, and appreciation from customers, which can boost employee effort and job satisfaction. This pattern of results is consistent with the pattern of results we observed in the field, in which food quality improved when the chefs could observe the customers, even though customers could not observe the chefs. We also find some support for the idea that seeing one's customer increases the perceived impact of one's work, which also increases effort and job satisfaction. Finally, although our results suggest that transparency can increase the feeling of being monitored, perceived monitoring is not related to effort or job satisfaction.

\section{Discussion}

From restaurants that adopt open-kitchen designs, to schools that "flip the classroom" and enable teachers and students to observe each others' efforts, to hospitals that encourage doctors to make decisions in collaboration with their patients, our results suggest that consumers may not be the sole beneficiaries of such innovations in transparency. Operational transparency that allows visual access between customers and employees essentially positions both parties as actor and observer, each with the potential to benefit from the other, and in ways that create perceived and objective value. Seeing the work can cause customers to better appreciate the effort exerted by employees, increasing their perceptions of service value. Seeing the customer can cause employees to feel more appreciated and that their work is more impactful, which in turn, can increase their job satisfaction and willingness to exert effort, resulting in better performance.

We note that these gains in performance can be economically meaningful. In our primary field experiment, the introduction of reciprocal transparency contributed to a $22.2 \%$ increase in customer-reported quality and reduced throughput times to $80.8 \%$ of standard in our fully specified models. To the extent that implementing transparency may be less costly and disruptive than alternative approaches for improving performance, our results therefore cast transparency as one additional lever that service managers may consider for improvements in the efficiency of their processes and the quality of outcomes they deliver. Furthermore, by introducing transparency, we suggest that companies can imbue operational processes with substantive meaning for customers and employees alike, in ways that could potentially benefit the company. Enhancing customer perceptions and appreciation for the effort expended and increasing customer perceptions of service value could promote top-line gains through improved satisfaction and loyalty. Helping employees feel more appreciated and satisfied could reduce costs by decreasing turnover. Moreover, increasing their sense of accountability to the customer, and their willingness to exert effort may reduce the need for monitoring, resulting in further cost savings. 
Given the reciprocity inherent in the mechanisms underlying these effects, we acknowledge that consumer or producer-side breakdowns may inhibit gains. For example, transparency may not improve consumer perceptions when service processes are unappealing, service outcomes are deemed unfavorable, or when transparency makes it salient that work is not being performed. Revealing the process that delivered a dissatisfying result has been shown to reduce perceptions of service value (Buell and Norton 2011), and to the extent that transparency reveals that a process is failing to keep up with the demand for its service, it may be no more helpful than not being transparent at all (Buell and Norton 2013). Furthermore, transparency may not increase quality and efficiency when producers are already operating at peak capacity (Kc and Terwiesch 2009, Oliva and Sterman 2001).

Understanding the contextual factors and boundary conditions that influence the effects of operational transparency on service outcomes remains a fruitful area for future research, particularly given the broad professional and lay interest in transparency. For example evidence suggests that consumers may inherently prefer operationally transparent designs. When we surveyed a separate set of 103 participants $\left(57.9 \%\right.$ female; $\left.M_{\text {age }}=33.54, S D=11.77\right)$ about their attitudes toward transparency, we found that a significant majority (76\%) believed that their lives would be enriched by having more face-to-face interactions, $\chi^{2}(1, N=103)=27.27, P<0.01$. Similarly, participants would be willing to pay more if they received their preferred degree of in-person service during consumer transactions, $t(102)=4.78, P<0.01$.

However, open questions abound. For example, although the present work explores the impact of transparency without interaction, the net effect of interactive operational transparency, in which customers and employees can directly communicate with one another, has not yet been explored. On the one hand, interaction may facilitate information sharing, which could mitigate rework and improve efficiency, while promoting familiarity among customers and employees. On the other hand, interaction may be distracting and foster negative exchanges, worsening experiences and diminishing efficiency. Another open question is the persistence of these effects. Although our results were consistent throughout our period of analysis, the long-term effects of operational transparency among customers and employees remain undocumented.

Our results suggest that by leveraging operational transparency to grant producers and consumers reciprocal access to visual information, organizations have the potential to tap into a virtuous cycle that enhances both perceived and objective service performance. In a culture where speed and automaticity often trump other values, we suggest that seeing and appreciating the people who help us, and allowing them to see us in return, can lead to experiences that are objectively better and more fulfilling for everyone involved. 


\section{References}

Alder, Stoney, Maureen Ambrose. 2005. Feedbacks influence on the perceived fairness of computer performance monitoring: An empirical investigation. Organizational Behavior and Human Decision Processes $97161-177$.

Ambady, Nalini, Robert Rosenthal. 1993. Half a minute: Predicting teacher evaluations from thin slices of nonverbal behavior and physical attractiveness. Journal of Personality and Social Psychology 64 $431-441$.

Axelrod, Joel N. 1968. Attitude measures that predict purchase. Journal of Advertising Research 8(1) 3-17.

Baker, Julie, Michaelle Cameron. 1996. The effects of the service environment on affect and consumer perception of waiting time: An integrative review and research propositions. Journal of the Academy of Marketing Science 24 338-349.

Barasch, Alixandra, Emma Levine, Jonathan Berman, Deborah Small. 2014. Selfish or selfless? On the signal value of emotion in altruistic behavior. Journal of Personality and Social Psychology 107 393-413.

Bartlett, Monica Y, David DeSteno. 2006. Gratitude and prosocial behavior. Psychological Science 17(4) $319-325$.

Bearden, WO, JE Teel. 1983. Selected determinants of consumer satisfaction and complaint reports. Journal of Marketing Research 20 21-28.

Benjamin, Daniel J., Jesse M. Shapiro. 2009. Thin-slice forecasts of gubernatorial elections. Review of Economics and Statistics 91 523-536.

Bernstein, Ethan S. 2012. The transparency paradox: A role for privacy in organizational learning and operational control. Administrative Science Quarterly 57(2) 181-216.

Boulding, William, Ajay Kalra, Richard Staelin, Valarie a. Zeithaml. 1993. A dynamic process model of service quality: From expectations to behavioral intentions. Journal of Marketing Research 307.

Brown, S. P., T. W. Leigh. 1996. A new look at psychological climate and its relationship to job involvement, effort, and performance. Journal of Applied Psychology 81 358-368.

Brown, Shona L, Kathleen M Eisenhardt. 1997. The art of continuous change: Linking complexity theory and time-paced evolution in relentlessly shifting organizations. Administrative Science Quarterly 42(1) $1-34$.

Buell, Ryan W., Michael I. Norton. 2011. The labor illusion: How operational transparency increases perceived value. Management Science 57(9) 1564-1579.

Buell, Ryan W., Michael I. Norton. 2013. Surfacing the submerged state with operational transparency in government services. Harvard Business School Working Paper 14-034 1-23.

Burke, Lee, Jeanne M. Logsdon. 1996. How corporate social responsibility pays off. Long Range Planning 29 495-502. 
Campbell, Margaret C., Amna Kirmani. 2000. Consumers' Use of Persuasion Knowledge: The Effects of Accessibility and Cognitive Capacity on Perceptions of an Influence Agent. Journal of Consumer Research 27 69-83.

Chalykoff, John, Thomas A Kochan. 1989. Computer-aided monitoring: Its Influence on employee Job satisfaction and turnover. Personnel Psychology 42 807-834.

Chase, Richard B. 1978. Where does the customer fit in a service operation? Harvard Business Review 56(6) $137-142$.

Chase, Richard B. 1981. The customer contact approach to services: Theoretical bases and practical extensions. Operations Research 29(4) 698.

Chassin, M. R., R. W. Galvin. 1998. The urgent need to improve health care quality. Institute of Medicine National Roundtable on Health Care Quality. Journal of the American Medical Association 280 10001005.

Chinander, Karen R., Maurice E. Schweitzer. 2003. The input bias: The misuse of input information in judgments of outcomes. Organizational Behavior and Human Decision Processes $91(2)$ 243-253.

Churchill Jr., G A, C Surprenant. 1982. An investigation into the determinants of customer satisfaction. Journal of Marketing Research 4 491-504.

Cialdini, Robert B. 2009. Influence: Science and Practice, vol. 3. Allyn \& Bacon, Boston.

Conger, J. A., R. N. Kanungo. 1988. The empowerment process: Integrating theory and practice. Academy of Management Review 13(3) 471-482.

Cronin Jr., J Joseph, Steven A Taylor. 1992. Measuring service quality: A reexamination and extension. The Journal of Marketing 56(3) 55-68.

Crowston, Kevin, James Howison, Hala Annabi. 2006. Information systems success in free and open source software development: theory and measures. Software Process: Improvement and Practice 11 123-148.

Deo, Sarang, Aditya Jain, Pradeep Pendem. 2014. Pacing work in the presence of goals and deadlines: Econometric analysis of an outpatient department.

Dhaliwal, Dan S., Oliver Zhen Li, Albert Tsang, Yong George Yang. 2011. Voluntary nonfinancial disclosure and the cost of equity capital: The initiation of corporate social responsibility reporting. Accounting Review 86 59-100.

Du, Shuili, C B Bhattacharya, Sankar Sen. 2007. Convergence of interests-cultivating consumer trust through corporate social initiatives. Advances in Consumer Research 34687.

Edwards, C D. 1968. The meaning of quality. Quality Progress 1(10) 36-39.

Fast, Nathanael J, Ethan R Burris, Caroline A Bartel. 2014. Managing to stay in the dark: Managerial self-efficacy, ego defensiveness, and the aversion to employee voice. Academy of Management Journal 57 1013-1034. 
Fornell, Claes, Robert A Westbrook. 1979. An exploratory study of assertiveness, aggressiveness, and consumer complaining behavior. Advances in Consumer Research 6 105-111.

Franke, Nikolaus, Peter Keinz, Katharina Klausberger. 2013. Does this sound like a fair deal?: Antecedents and consequences of fairness expectations in the individuals decision to participate in firm innovation. Organization Science 24(5) 1495-1516.

Franke, Nikolaus, Martin Schreier, Ulrike Kaiser. 2010. The I designed it myself effect in mass customization. Management Science 56 125-140.

Friedrich, J, P Barnes, K Chapin, I Dawson, V Garst, D Kerr. 1999. Psychophysical numbing: When lives Are valued less as the lives at risk increase. Journal of Consumer Psychology 8 277-299.

Fuchs, Christoph, Martin Schreier. 2011. Customer empowerment in new product development. Journal of Product Innovation Management 28 17-32.

Garvin, David A. 1984. What does product quality really mean? Sloan Management Review (pre-1986) 26(1) 25.

Gilmore, H. L. 1974. Product conformance cost. Quality Progress 7(5) 16-19.

Gino, Francesca, Lisa L. Shu, Max H. Bazerman. 2010. Nameless + harmless = blameless: When seemingly irrelevant factors influence judgment of (un)ethical behavior. Organizational Behavior and Human Decision Processes 111 93-101.

Grant, Adam M. 2007. Relational job design and the motivation to make a prosocial difference. Academy of Management Review 32 393-417.

Grant, Adam M., Elizabeth M. Campbell, Grace Chen, Keenan Cottone, David Lapedis, Karen Lee. 2007. Impact and the art of motivation maintenance: The effects of contact with beneficiaries on persistence behavior. Organizational Behavior and Human Decision Processes 103(1) 53-67.

Gremler, D. D., K. P. Gwinner. 2000. Customer-employee rapport in service relationships. Journal of Service Research 3 82-104.

Hackman, J. Richard, Diane Coutu. 2009. Why teams don’t work. Harvard Business Review 87(5).

Hackman, J. Richard, Ruth Wageman. 2004. When and how team leaders matter. Research in Organizational Behavior 26 37-74.

Haley, Russell I, Peter B Case. 1979. Testing thirteen attitude scales for agreement and brand discrimination. Journal of Marketing 43 20-32.

Hartline, M. D., O. C. Ferrell. 1996. The management of customer-contact service employees : An empirical investigation. Journal of Marketing 60(4) 52-70.

Hochwarter, W. A., C. J Kacmar, G. R. Ferris. 2003. Accountability at work: An examination of antecedents and consequences. Annual Meeting of the Society of Industrial and Organizational Psychology. Orlando, Florida. 
Jacob, Brian A., Lars Lefgren. 2008. Can principals identify effective teachers? Evidence on subjective performance evaluation in education. Journal of Labor Economics 26 101-136.

Jha, Ashish K. 2006. Measuring hospital quality: What physicians do? How patients fare? Or both? Journal of the American Medical Association 296(1) 95-97.

Johnson School, Cornell University, Gerson Lehrman Group. 2012. Food Service Trends in Emerging Markets. Tech. rep., Johnson School, Cornell University; Gerson Lehrman Group.

Kc, Diwas S., Christian Terwiesch. 2009. Impact of workload on service time and patient safety: An econometric analysis of hospital operations. Management Science 55 1486-1498.

Kruger, Justin, Derrick Wirtz, Leaf Van Boven, T William Altermatt. 2004. The effort heuristic. Journal of Experimental Social Psychology 40(1) 91-98.

Lo, Kin. 2003. Economic consequences of regulated changes in disclosure: The case of executive compensation. Journal of Accounting and Economics 35 285-314.

Malhotra, D., M. Bazerman. 2007. Conflicts of Interest. Leadership Excellence 2416.

McAlexander, James H., John W. Schouten, Harold F. Koenig. 2002. Building brand community. Journal of Marketing 66 38-54.

McDougall, Gordon H. G., Terrence Levesque. 2000. Customer satisfaction with services: Putting perceived value into the equation. Journal of Services Marketing 14(5) 392-410.

Mohan, Bhavya, Ryan W. Buell, Leslie K. John. 2014. Lifting the veil: The benefits of cost transparency.

Mohr, Lois A., Mary Jo Bitner. 1995. The role of employee effort in satisfaction with service transactions. Journal of Business Research 32(3) 239-252.

Morales, Andrea C. 2005. Giving firms an E for effort: Consumer responses to higheffort firms. Journal of Consumer Research 31(4) 806-812.

National Restaurant Association. 2015. 2015 Facts at a Glance. URL http://www.restaurant.org/ News-Research/Research/Facts-at-a-Glance.

Neergaard, L, D Caruso. 2014. Ebola: NY had jump-start, Dallas had to learn fast.

Norton, Michael I, Daniel Mochon, Dan Ariely. 2011. The IKEA effect: When labor leads to love. Journal of Consumer Psychology 22(3) 453-460.

Oliva, Rogelio, John D. Sterman. 2001. Cutting corners and working overtime: Quality erosion in the service industry. Management Science 47(7) 894-914.

Pan, Yue, George M. Zinkhan. 2006. Exploring the impact of online privacy disclosures on consumer trust. Journal of Retailing 82 331-338.

Parasuraman, A, Valarie A Zeithaml, Leonard L Berry. 1985. A conceptual model of service quality and its implications for future research. Journal of Marketing 49(4) 41-50. 
Pierce, Jason R, Gavin J Kilduff, Adam D Galinsky, Niro Sivanathan. 2013. From glue to gasoline: how competition turns perspective takers unethical. Psychological Science 24 1986-94.

Plassmann, Hilke, John O'Doherty, Baba Shiv, Antonio Rangel. 2008. Marketing actions can modulate neural representations of experienced pleasantness. Proceedings of the National Academy of Sciences of the United States of America, vol. 105. 1050-1054.

Regan, Dennis T. 1971. Effects of a favor and liking on compliance. Journal of Experimental Social Psychology $7627-639$.

Robinson, Thomas N, Dina L G Borzekowski, Donna M Matheson, Helena C Kraemer. 2007. Effects of fast food branding on young children's taste preferences. Archives of Pediatrics \&3 Adolescent Medicine $\mathbf{1 6 1}$ $792-797$.

Ross, Lee, Constance Stillinger. 1991. Barriers to conflict resolution. Negotiation Journal 7 389-404.

Rule, Nicholas O., Nalini Ambady. 2008. The face of success: inferences from chief executive officers' appearance predict company profits. Psychological Science 19 109-111.

Rusbult, Caryl E. 1979. Commitment and satisfaction in romantic associations: A test of the investment model. Journal of Experimental Social Psychology 16 172-186.

Small, Deborah A., George Loewenstein. 2005. The devil you know: The effects of identifiability on punishment. Journal of Behavioral Decision Making 18 311-318.

Snipes, Robin L., Sharon L. Oswald, Michael LaTour, Achilles A. Armenakis. 2005. The effects of specific job satisfaction facets on customer perceptions of service quality: an employee-level analysis. Journal of Business Research 58(10) 1330-1339.

Spence, Charles, Carmel A. Levitan, Maya U. Shankar, Massimiliano Zampini. 2010. Does food color influence taste and flavor perception in humans? Chemosensory Perception 3 68-84.

Sweeney, Jillian C., Geoffrey N. Soutar. 2001. Consumer perceived value: The development of a multiple item scale. Journal of Retailing 77(2) 203-220.

Tansik, D. A., R. B. Chase. 1983. The customer contact model for organization design. Management Science 29 1037-1050.

Thompson, J. D. 1967. Organizations in action. McGraw-Hill, New York.

Thoms, Peg, Jennifer J. Dose, Kimberly S. Scott. 2002. Relationships between accountability, job satisfaction, and trust. Human Resource Development Quarterly 13 307-323.

Tidd, K. L., J. S. Lockard. 1978. Monetary significance of the affiliative smile: A case for reciprocal altruism. Bulletin of the Psychonomic Society 11 344-346.

Torelli, Carlos J., Alokparna Basu Monga, Andrew M. Kaikati. 2012. Doing poorly by doing good: Corporate social responsibility and brand concepts. Journal of Consumer Research 38 948-963. 
Tsai, J. Y., S. Egelman, L. Cranor, A. Acquisti. 2010. The effect of online privacy information on purchasing behavior: An experimental study. Information Systems Research 22 254-268.

Tsay, Chia-Jung. 2013. Sight over sound in the judgment of music performance. Proceedings of the National Academy of Sciences of the United States of America 110 14580-5.

Tsay, Chia-Jung. 2014. The vision heuristic: Judging music ensembles by sight alone. Organizational Behavior and Human Decision Processes 124(1) 24-33.

Tse, D, P Wilton. 1988. Models of consumer satisfaction formation: an extension. Journal of Marketing 25 $204-212$.

Walfried, Lassar, Chris Manolis, Robert D. Winsor. 2000. Service quality perspectives and satisfaction in private banking. Journal of Services Marketing 14(3) 244-271.

Wathieu, Luc. 2004. Consumer habituation. Management Science 50(5) 587-596.

Yoon, Yeosun, Zeynep Gürhan-Canli, Norbert Schwarz. 2006. The effect of corporate social responsibility (CSR) activities on companies With bad Reputations. Journal of Consumer Psychology 16(4) 377-390.

Zellner, D A, M A Kautz. 1990. Color affects perceived odor intensity. Journal of Experimental Psychology. Human perception and Performance 16(2) 391-397.

Zweig, David, Jane Webster. 2002. Where is the line between benign and invasive? An examination of psychological barriers to the acceptance of awareness monitoring systems. Journal of Organizational Behavior 23 605-633.

\section{Acknowledgments}

We thank Arleen Chien, Zaki Djemal, Joseph Hall, Elena Helgiu, and Kate Metzinger for their tireless support during data collection; Doug Chung, Daniel Malter, Michael Norton, William Simpson, Tatiana Sandino, Pian Shu, Michael Toffel, Charles Wang, Alison Wood Brooks, the UCL MSI Reading Group, and seminar participants at Boston University, Vanderbilt University, University of Southern California, The Ohio State University, Harvard Business School, the 2014 POMS Annual Conference, the 2014 MSOM Service Special Interest Group Conference, and the 2013 and 2014 INFORMS annual conferences for their helpful comments and suggestions; and Jean Adams, Becky Donner, Mary Lou Kearns, Kristine Kirk, Steven Livingston, Crista Martin, Melissa Ouellet, and Mindi Rock for their invaluable assistance. All errors remain our own. 